\title{
Objects, Worlds, and Students: Virtual Interaction in Education
}

\author{
Athanasios Christopoulos, Marc Conrad, and Mitul Shukla \\ Department of Computer Science \& Technology, University of Bedfordshire, Park Square, Luton LU1 3JU, UK \\ Correspondence should be addressed to Athanasios Christopoulos; athanasios.christopoulos@beds.ac.uk
}

Received 31 May 2014; Revised 28 August 2014; Accepted 30 August 2014; Published 22 September 2014

Academic Editor: Shu-Sheng Liaw

Copyright (C) 2014 Athanasios Christopoulos et al. This is an open access article distributed under the Creative Commons Attribution License, which permits unrestricted use, distribution, and reproduction in any medium, provided the original work is properly cited.

\begin{abstract}
The main aim of this study is to form a complete taxonomy of the types of interactions that relate to the use of a virtual world for engaging learning experiences, when blended and hybrid learning methods are to be used. In order to investigate this topic more accurately and effectively, we distinguish four dimensions of interactions based on the context in which these occur, and the involved parts: in-world and in-class, user-to-user and user-to-world interactions. In order to conduct investigation into this topic and form a view of the interactions as clear as possible, we observed a cohort of 15 undergraduate Computer Science students while using an OpenSim-based institutionally hosted virtual world. Moreover, we ran a survey where 50 students were asked to indicate their opinion and feelings about their in-world experience. The results of our study highlight that educators and instructors need to plan their in-world learning activities very carefully and with a focus on interactions if engaging activities are what they want to offer their students. Additionally, it seems that student interactions with the content of the virtual world and the in-class student-to-student interactions, have stronger impact on students' engagement when hybrid methods are used.
\end{abstract}

\section{Introduction}

Over the past few decades, technology has proven to be a useful tool in educators' hands and, thus, has attracted researchers' interest. Technology relates to education in four different ways, that is, technology as a topic ("learning about technology"), technology as a delivery mechanism ("learning from technology"), technology as a tool ("learning with technology"), and technology as the context in which learning takes place ("learning in technology") [1]. Virtual reality and virtual worlds, which were first introduced to the public in 1980s and have continued to emerge ever since [2], are the cornerstones of "learning in technology" [1].

In the literature $[2,3]$, virtual worlds are defined as $2 \mathrm{D}$ or $3 \mathrm{D}$ computer generated environments that either depict parts of the physical world or imaginary sceneries. In these worlds, users are able to perform a wide range of interactions with the content of the world and other users [4], such as object creation [5,6] and manipulation [6,7], terrain editing [5], and navigating around the world $[2,5,6,8,9]$, as well as chatting synchronously or asynchronously, either verbally via voice or written chat or nonverbally using avatar gestures and other forms of in-world visual interactions [6-10]. These kinds of interactions are performed through the use of avatars $[2,5,7$, $8]$, that is, users' artificial figures $[4,11]$.

The fact that virtual worlds provide the necessary context for all those interactions mentioned and are increasingly providing more complex ones has led educators to use them extensively, taking into account all their educational potentials [1]. Content creation activities, exploratory, problembased, collaborative, blended, and synchronous or asynchronous distance learning are only some of the few inworld educational paradigms that have been extensively used and studied from many different perspectives $[4,9,10,12]$. Despite some differentiations on recent researches' foci [1316], Vygotsky's Social Constructivist Learning Theory [17] claimed to have great practical application on learning within virtual worlds. According to [17] students construct their cognitive structures through interactions, and engagement in any kind of activity motivates them to learn. Thus, interacting within virtual worlds can be very beneficial for learners [6]. The author in [18] underlines that it is the learners' ability to affect, alter, and enhance, according to their needs, the content of the virtual world they learn in that enables 
them to construct their cognitive schemes and engage with the phenomena they study. Consequently, learning becomes more self-directed and student-centered [19], whilst the educators get the role of designers, instructor, and supporter of activities that aim to engage students in learning $[1,20]$.

Several frameworks have been developed to aid educators define and conceptualise their new role and the potential utilisations of virtual worlds in educational contexts [21]. Most of them focus on the interactivity of the worlds or the interactions that can-or need to-be developed in order to cover student's learning needs. Camilleri et al. [22] studied in detail the in-world interactions aiming to explain how students learn in-world but disregarded the perspective of learning in the physical classroom, focusing on the viewpoint of distance-learning.

Likewise, de Freitas et al. [23], investigating the use of virtual worlds for distance learning, suggested a fourdimensional framework for the evaluation of student learning experiences. Those dimensions are, namely, learners' dimension (profile, role, and competencies), pedagogic dimension (associative, cognitive, and social/situative), representational dimension (fidelity, interactive, and immersion), and contextual dimension (environment, access to learning and supporting resources). Even though in-world interactions were part of their study, the focus was not exclusively on that aspect since they aimed to give a more holistic view of the affordances of distance education in virtual worlds.

Childs, [24] who investigated the skills students acquire when they start using virtual worlds, formed a taxonomy of interactions related to the use of virtual words. He divided interactions into four categories: interacting with the world (motion, maneuvering, way-finding, changing camera positions, and using mouselook), interacting with others (using local chat, using private chat, and using the minimap to find people and move to them), interacting with the avatar (changing avatar appearance, creating folders to save appearances, and animating the avatar), and finally finding and searching (creating a landmark, finding a landmark in the inventory, and teleporting to a new location and back again). This taxonomy did not include the interactions between students, the content of the world, nor the building and scripting skills students usually need to acquire, since this subject was out of the scope of his study and, additionally, it was not in his participants' agenda to create in-world content.

Chafer and Childs [25] identified the elements that affect a world's interactivity, that is, manipulability, reciprocation, and responsiveness. Addressing the same topic from a different angle, Steuer [26] noted three alternative factors when examining interactivity: speed, range, and mapping of interactions. These two different frameworks can be truly helpful tools for educators who need to measure how interactive their existing virtual environments are.

One of the few researches looking at the educational use of virtual worlds both from the inside and from the outside-both in-world and in-class-is that of Levesque and Lelievre [27]. Specifically, they presented the outcome of their experiment on applying a hybrid approach, where students were simultaneously present in-class and in-world. They pointed out the complex network of interactions that was developed both in-world and in-class, both among and between students, and the virtual environment.

De Freitas et al. [28] underline the need for further investigation of the potential and affordances of hybrid spaces with simultaneous student physical and virtual presence. Further, Elliott et al. [21] point out a lack of a detailed taxonomy of all the interactions related to the use of virtual worlds in educational context, which would aid in a better understanding of virtual worlds' affordances, in more expedient design of educational activities, and in a more thorough exploitation of their potentials.

Therefore, this paper is focusing on mapping and taxonomising the various types of interactions that take place both in-class and in-world, when a hybrid approach is used, having access both to the person who interacts-real identity - and to the avatar-virtual identity. This is only the first part of our ongoing research that has as its final goal the creation of a framework that will become a substantial guide for educators who need engaging learning experiences for their students.

The following sections provide the reader a clear view of the course undertaken for the investigation of the research topic and the creation of the taxonomy. In Section 2, detailed information is provided about the research methods used, whilst Section 3 focuses on the research results analysis and the corresponding discussion. Specifically, Sections 3.1 and 3.2 refer to the data derived from the survey, which was the first research method used, and Sections 3.3 and 3.4 refer to the observatory data collected. The triangulation of the collected data is presented in Section 3.5 and the paper concludes with the experiment and the presentation of the taxonomy.

\section{Materials and Methods}

This case study took place in December, 2013, with a cohort of undergraduate Computer Science and Technology students, in the context of the comparative integrated systems unit. An institutionally hosted OpenSim server was used in order to allow students to explore and familiarize themselves with the Linden Scripting Language (LSL). Their task was to build and script anything they would like, based on a scenario, using their imagination, all the in-world tools, and their programming skills. Students had the opportunity to decide whether they would work in groups of two or individually, but in either case, at the end of this assignment all students were expected to perform a five-minute individual presentation of their work followed by the submission of a report. The practical sessions of this unit were two hours each and run once a week. The entire experiment was conducted within a period of four weeks with the participation of seventy-five students.

Aiming to cover the needs of this study, two research methods were used in the context of the comparative integrated systems unit: observations and survey. The use of two research methods, one of them being qualitative and one quantitative, was thought to be the most appropriate, since it would aid validity and diversity, give a more thorough 
view of the phenomena, and allow for the triangulation of the primary data. In other words, observations were used to record student actions and behavior both in the physical classroom and in the virtual world, whilst surveys were used to record preferences.

Even though research through observations may have several strengths [29], three were the main aspects that indicated observations as the most suitable method for this study. Firstly, what is considered to be the most essential advantage of observations is the principles of "immediate awareness" and "direct cognition" as described in [29] that lead to the emergence of unique and valid primary data. Secondly, it is a very flexible form of data collection that allows researchers to alter their focus from one aspect to another, depending on the observed actions and behaviors. Finally, the method of observation is a participant-friendly method: while observation is taking place the participants can follow their own agenda and priorities.

Survey has numerous advantages according to [29], but four of them were the ones that led us to use this research method. First of all, it is thought to be the most sufficient method to gather the opinions of a large-scale sample, given that not all students could take part in the observations; thus practical reasons were a crucial criterion. Moreover, the data gathered from the survey were thought to be used supplementarily to those gathered from observations, since these would reveal students' thoughts about the use of the virtual world and justify their actions and behaviors. In addition, it allows statistical analysis and considerably accurate generalizations. Finally, it is thought to be participantfriendly, since it is widely used and participants are familiar with it and it is also quick and easy to answer, especially because it is multiple-choice compiled according to a Likert scale.

Using both qualitative and quantitative methods-that is, both surveys and observations in our case-has two significant advantages [29]: (a) it allows researchers to have a wider, more reliable, and substantial view of complex human behaviors and (b) it overcomes the limitations that each research method separately may have, especially when combining quantitative and qualitative research methods.

2.1. Survey. The questionnaire consisted of thirty (30) statements on a five-point Likert scale (Strongly Agree to Strongly Disagree) and was divided in two parts: the first part (14 statements-see Table 2) examined students' interactions with the content of the virtual world in the context of the practical sessions and the second part (16 statements-see Table 3) examined students' interactions with other users of the virtual world in the context of the practical sessions.

Fifty (50) undergraduate students participated in the survey answering the questionnaire. Fifteen (15) of them accessed it electronically (Google docs) and thirty-five (35) opted to answer through a hard copy version. More than $2 / 3$ of the participants were male $(68 \%)$ and only less than $1 / 3$ were female $(32 \%)$. The vast majority of participants $(82 \%)$ were aged $18-25$ years old, a few were $26-35$ years old (16\%),
TABLE 1: Direct comparison of students' responses.

\begin{tabular}{lccc}
\hline Interactions & $\begin{array}{c}\text { Positive } \\
\text { responses }\end{array}$ & $\begin{array}{c}\text { Neutral } \\
\text { responses }\end{array}$ & $\begin{array}{c}\text { Negative } \\
\text { responses }\end{array}$ \\
\hline Student-to-world & 35.5 & 10.64 & 3.86 \\
Student-to-student & 33.13 & 12.3 & 4.63 \\
\hline
\end{tabular}

only one was $36-45$ years old, and none was older than 45 years old.

2.2. Observations. Fifteen (15) self-selected students, with no prior experience in the use of virtual worlds like OpenSim, agreed to be observed in-world and in-class while working on their assignment. Ten (10) of them were male and five (5) female, whilst eleven (11) were aged 18-25 and four (4) 26-36 years old.

Semistructured observational check lists were used for the collection of the primary data. A narrative approach, as described in [29], was thought to be the most suitable for the analysis of this data. Through this approach, student behavior, choices, and actions could be studied in the context in which they took place. Also, narratives were in logical structures rather than in a chronological order. The focus of the analysis was on behavior, choices, and actions.

\section{Results and Discussion}

3.1. Data Gathered from the Survey. The majority of participants agreed to all given statements, while in all cases the total of positive responses ("Strongly Agree" and "Agree") was higher than the total of negative responses ("Strongly Disagree" and "Disagree"). Moreover, participants chose the neutral response ("Neither Agree nor Disagree") quite frequently, since the neutral response was given more often than both negative responses in all statements and the extreme positive responses in many, yet not all, statements. The analytical results of the survey are presented in Tables 2 and 3.

In a first attempt to compare students' responses regarding student-to-world interactions and student-to-student interactions, Table 1 demonstrates the number of positive, neutral, and negative responses students gave to each set of statements. Student-to-world interactions had slightly more positive results than student-to-student interactions, whilst statements regarding student-to-student interactions gathered more neutral and negative responses than those regarding student-to-world interactions. More precisely, statements regarding student-to-world interactions had, in average, 35.5 positive, 10.6 neutral, and 3.86 negative responses. On the other hand, statements regarding student-to-world interactions had, in average, 33.13 positive, 12.3 neutral, and 4.63 negative responses.

A comparative analysis on the responses given to the same statements of each part of the questionnaire follows. This comparison is considered much needed, since student-to-student interactions and student-to-world interactions greatly affect students' engagement, as already noted 


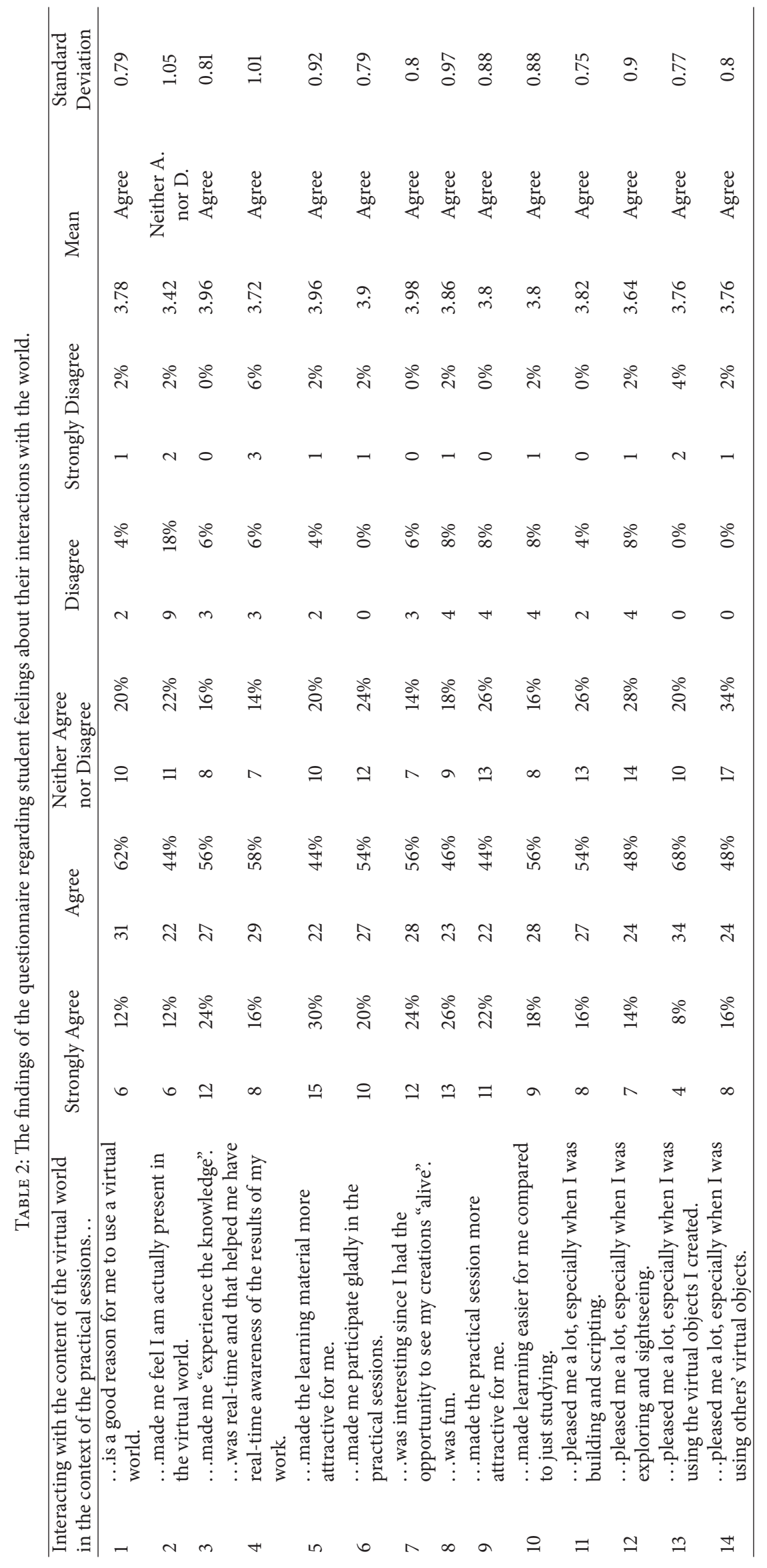




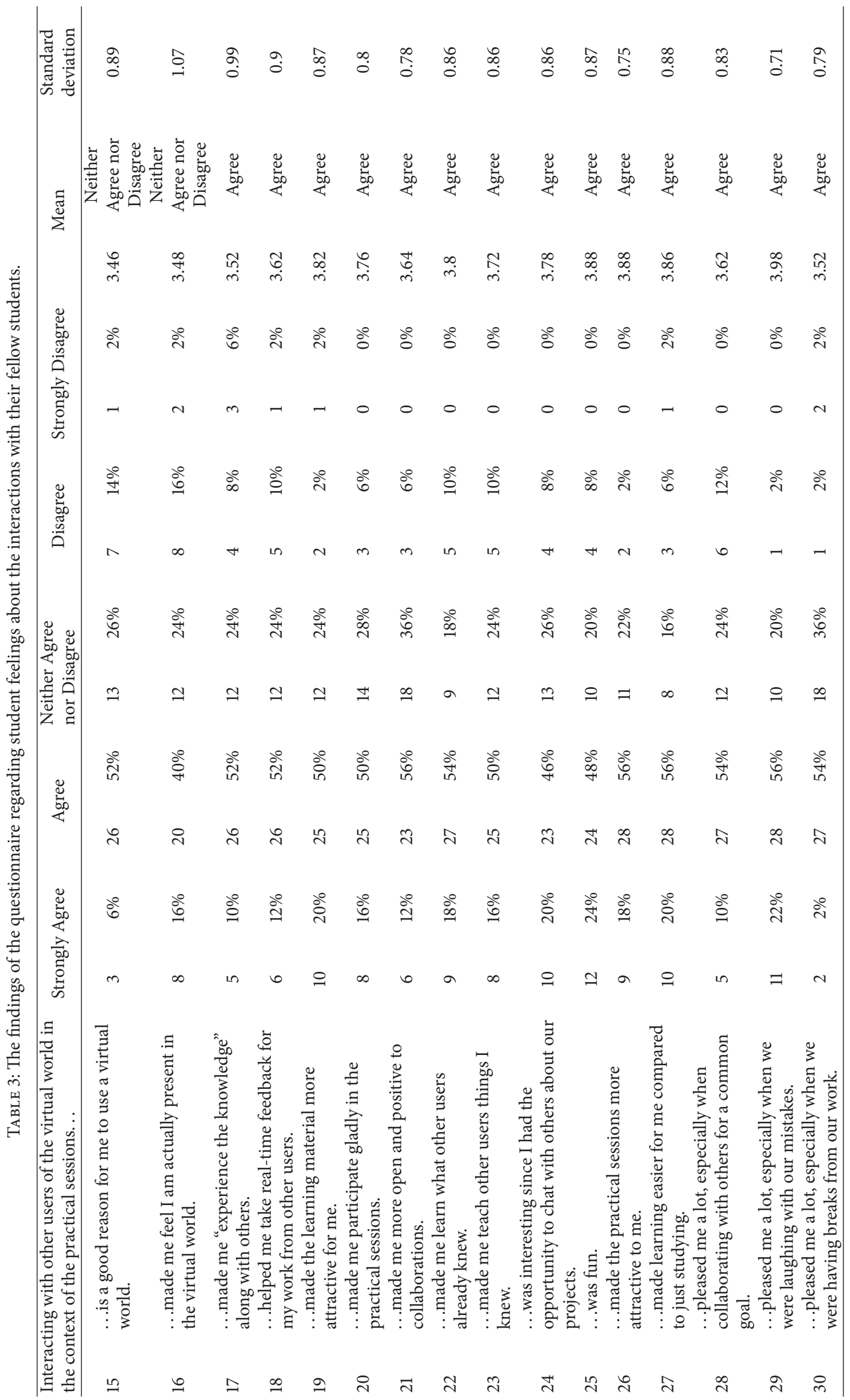


TABLE 4: Results of statements 1 and 15 of the survey $(n=50)$.

\begin{tabular}{lccccccc}
\hline $\begin{array}{l}\text {. is a good reason for me to } \\
\text { use a virtual world. }\end{array}$ & $\begin{array}{c}\text { Strongly } \\
\text { Agree }\end{array}$ & Agree & $\begin{array}{c}\text { Neither } \\
\text { Agree nor } \\
\text { Disagree }\end{array}$ & Disagree & $\begin{array}{c}\text { Strongly } \\
\text { Disagree }\end{array}$ & $\begin{array}{c}\text { Mean } \\
\text { Standard } \\
\text { deviation }\end{array}$ \\
\hline 1 & Student-to-world & 6 & 31 & 10 & 2 & 1 & 3.78 \\
15 & Student-to-student & 3 & 26 & 13 & 7 & 1 & 3.46 \\
\hline
\end{tabular}

TABLE 5: Results of statements 2 and 16 of the survey $(n=50)$.

\begin{tabular}{lccccccc}
\hline $\begin{array}{l}\text {. made me feel I am actually } \\
\text { present in the virtual world. }\end{array}$ & $\begin{array}{c}\text { Strongly } \\
\text { Agree }\end{array}$ & Agree & $\begin{array}{c}\text { Neither } \\
\text { Agree nor } \\
\text { Disagree }\end{array}$ & Disagree & $\begin{array}{c}\text { Strongly } \\
\text { Disagree }\end{array}$ & $\begin{array}{c}\text { Mean } \\
\text { Standard } \\
\text { deviation }\end{array}$ \\
\hline 2 & Student-to-world & 6 & 22 & 11 & 9 & 2 & 3.42 \\
16 & Student-to-student & 8 & 20 & 12 & 8 & 2 & 3.48 \\
\hline
\end{tabular}

[5, 24, 30-32]. Moreover, given that this case study ran as a preliminary research aiming to map students' in-world interactions and their effects, this comparison seemed to be even more necessary for the formation of the first substantial outcomes that would work as cornerstone for the future development of the study.

However, these results cannot be seen individually. Thus, it is suggested that the reader should study them in conjunction with the findings of the observations that ran alongside the survey and are presented in Section 3.3.

Statements 1 and 15 (...is a good reason for me to use a virtual world.) (see Table 4). The majority of the participants agreed that their interactions with the content of the virtual world and with each other can be a good reason for them to use a virtual world. However, the number of participants who expressed a positive opinion on the statement about the student-to-world interactions was higher than that of the students who expressed a positive opinion about the student-to-student interactions, whilst the neutral and negative responses regarding student-to-student interactions were more compared to negative or neutral responses about student-to-world interactions.

Standard deviation on Statement 15 was quite high (0.89) and, even though the mode of the statement was "Agree", the mean (3.46) shows that the sample tended to "Neither Agree nor Disagree" on the statement. Standard deviation on Statement 1 was lower (0.79), the mean was higher (3.78), and both the mode and the trend of the sample are to "Agree" with the statement.

These findings indicate that participants would opt to use a virtual world mainly for the interactions they can have with the content of the virtual world and less for the interactions they can have in-world with other users. Indeed, as long as observations lasted, students hardly ever used the in-world communication tools, but they preferred to interact in-class and face-to-face with their class-mates instead (see Section 3.3).

Statements 2 and 16 (...made me feel I am actually present in the virtual world.) (see Table 5). The majority of participants agreed that interacting with the content of the virtual world and with each other made them have a sense of presence in the virtual world. Student-to-student interactions seem to have a slightly greater influence on students' sense of in-world presence than student-to-world interactions, since students' responses on the student-to-student statement were slightly more positive.

Even though the responses to both statements had a mode on "Agree," the fairly high standard deviation clearly demonstrated that the responses were greatly spread. More precisely, responses on Statement 2 with standard deviation up to 1.05 revealed that the sample tended to have a neutral position on the statement (3.42), whilst responses on Statement 16 with standard deviation up to 1.07 indicated that the sample tended to "Neither Agree nor Disagree" (3.48).

At this point, the incorrect conclusion that students were actually immersed must not be drawn. The number of negative and neutral responses was fairly high, too. The high percentage on the positive responses indicates that studentto-world interactions and student-to-student interactions have a positive effect on students' engagement and can potentially lead to them feeling present in the virtual world. The most useful outcome from these responses is that student-tostudent interactions and student-to-world interactions need to be enhanced when engaging learning experiences is the main reason for using virtual worlds.

Statements 3 and 17 (...made me "experience" the knowledge.) (see Table 6). More than half of the participants gave a positive response to the statement that student-to-student and student-to-world interactions made them experience the knowledge, in other words helped them learn by doing. This positive response comes in accordance with the findings of the relevant literature $[24,28,33]$. The statement regarding the influence of student-to-world interactions gathered more positive results compared to student-to-student interactions, whilst student-to-student interactions had more neutral and negative replies.

Both statements had mode on "Agree," but the replies to the student-to-student interactions statement were quite spread; a fact that is demonstrated by its standard deviation which is up to 0.99 . The replies on the student-toworld interactions statement were more concentrated around 
TABLE 6: Results of statements 3 and 17 of the survey $(n=50)$.

\begin{tabular}{lccccccc}
\hline $\begin{array}{l}\text {..made me "experience the } \\
\text { knowledge". }\end{array}$ & $\begin{array}{c}\text { Strongly } \\
\text { Agree }\end{array}$ & Agree & $\begin{array}{c}\text { Neither } \\
\text { Agree nor } \\
\text { Disagree }\end{array}$ & Disagree & $\begin{array}{c}\text { Strongly } \\
\text { Disagree }\end{array}$ & $\begin{array}{c}\text { Mean } \\
\text { Standard } \\
\text { deviation }\end{array}$ \\
\hline 3 & Student-to-world & 12 & 27 & 8 & 3 & 0 & 3.96 \\
17 & Student-to-student & 5 & 26 & 12 & 4 & 3 & 3.52 \\
\hline
\end{tabular}

TABLE 7: Results of statements 4 and 18 of the survey $(n=50)$.

\begin{tabular}{|c|c|c|c|c|c|c|c|}
\hline $\begin{array}{l}\text {...was real-time and that } \\
\text { helped me have real-time } \\
\text { awareness and feedback of the } \\
\text { results of my work. }\end{array}$ & $\begin{array}{c}\text { Strongly } \\
\text { Agree }\end{array}$ & Agree & $\begin{array}{l}\text { Neither } \\
\text { Agree nor } \\
\text { Disagree }\end{array}$ & Disagree & $\begin{array}{l}\text { Strongly } \\
\text { Disagree }\end{array}$ & Mean & $\begin{array}{l}\text { Standard } \\
\text { deviation }\end{array}$ \\
\hline Student-to-world & 8 & 29 & 7 & 3 & 3 & 3.72 & 1.01 \\
\hline Student-to-student & 6 & 26 & 12 & 5 & 1 & 3.62 & 0.9 \\
\hline
\end{tabular}

the "Agree" reply, as shown by its lower standard deviation (0.81). In general, participants tend to agree that both the student-to-student and student-to-world interactions help them experience the knowledge, but, overall, student-toworld interactions were rated more positively (3.96).

As shown by these findings, student-to-world interactions have greater impact on students experiencing the learning material than student-to-student interactions. In both cases, the highly positive results seem to point out that the virtual worlds can be useful tools for experiential learning, as they give students the chance to "live" the lesson and a more thorough investigation into this aspect of experiential learning would be desirable and might be the subject of a follow-up study.

Statements 4 and 18 (...was real-time and that helped me have real-time awareness and feedback of the results of my work.) (see Table 7). The vast majority of participants considered positively the fact that they could have real-time awareness and feedback on the results of their work through the various interactions taking place in-world. Once again, the student-to-world interactions gathered slightly more positive responses than student-to-student interactions, which gathered slightly more neutral and negative results. The fact that the statement regarding student-to-world interactions had more "Strongly Agree" and at the same time more "Strongly Disagree" replies than the statement regarding student-tostudent interactions is very interesting.

Even though standard deviation on Statement 4 was quite high (1.01) and the mode of the statement was "Agree," the mean (3.72) shows that the sample had a tendency to agree with the statement, too. Standard deviation on Statement 18 was lower (0.79) and both the mode and the trend (3.62) of the sample are to "Agree" with the statement.

According to participants, student-to-world interactions helped them have real-time awareness of the results of their work, and student-to-student interactions allowed them to have immediate feedback in-world from their classmates. However, they seem to consider the fact that, through their interactions with the world, they could see immediately their work progress more valuable.
Statements 5 and 19 (...made the learning material more attractive for me.) (see Table 8). The vast majority of participants agreed that interacting with the content of the virtual world and with each other made the learning material more attractive to them. The positive replies to both statements were very high and very few participants expressed a negative opinion.

The responses on both statements had mode and mean on "Agree." Despite the fact that standard deviation in both cases appears slightly high (0.92 in the case of student-toworld interactions and 0.87 in the case of student-to-student interactions) which signifies the wide range of the responses given, they are mostly positive, neutral, and not so negative.

It seems that the complex network of interactions occurring within a virtual world can have a very positive impact on the attractiveness of the learning material accessed in-world. This finding is in total agreement with the findings of the observation carried out with the same cohort of students (see Section 3.3).

Statements 6 and 20 (...made me participate gladly in the practical sessions.) (see Table 9). Most of the participants agreed or agreed strongly that both student-to-world and studentto-student interactions made them "participate gladly" in the practical sessions. The replies on the student-to-world statement were slightly more positive compared to those on the student-to-student statement, which gathered more neutral and negative replies. However, the statement about studentto-world interactions had a "Strongly Disagree" response, whilst the one about student-to-student interactions had none.

Both statements had mode and mean on the "Agree" response and almost equal standard deviations, that is, 0.79 for the statement regarding student-to-world interactions and 0.8 for the statement regarding student-to-student interactions. The responses on both statements were quite spread around the positive and neutral replies. According to the participants, the use of a virtual world and the fact that they had the chance to interact with its content and their fellow students in the context of a practical session made them engage gladly with their assignments. Students appear to be 
TABLE 8: Results of statements 5 and 19 of the survey $(n=50)$.

\begin{tabular}{lccccccc}
\hline $\begin{array}{l}\text {. made the learning material } \\
\text { more attractive for me. }\end{array}$ & $\begin{array}{c}\text { Strongly } \\
\text { Agree }\end{array}$ & Agree & $\begin{array}{c}\text { Neither } \\
\text { Agree nor } \\
\text { Disagree }\end{array}$ & Disagree & $\begin{array}{c}\text { Strongly } \\
\text { Disagree }\end{array}$ & $\begin{array}{c}\text { Mean } \\
\text { Standard } \\
\text { deviation }\end{array}$ \\
\hline 5 & Student-to-world & 15 & 22 & 10 & 2 & 1 & 3.96 \\
19 & Student-to-student & 10 & 25 & 12 & 2 & 1 & 3.82 \\
\hline
\end{tabular}

TABLE 9: Results of statements 6 and 20 of the survey $(n=50)$.

\begin{tabular}{lccccccc}
\hline $\begin{array}{l}\text {..made me participate gladly } \\
\text { in the practical sessions. }\end{array}$ & $\begin{array}{c}\text { Strongly } \\
\text { Agree }\end{array}$ & Agree & $\begin{array}{c}\text { Neither } \\
\text { Agree nor } \\
\text { Disagree }\end{array}$ & Disagree & $\begin{array}{c}\text { Strongly } \\
\text { Disagree }\end{array}$ & $\begin{array}{c}\text { Mean } \\
\text { Standard } \\
\text { Deviation }\end{array}$ \\
\hline 6 & Student-to-world & 10 & 27 & 12 & 0 & 1 & 3.9 \\
20 & Student-to-student & 8 & 25 & 14 & 3 & 0 & 3.76 \\
\hline
\end{tabular}

happy to participate in the practical sessions mostly because of the chance they had to interact with the world rather than because of the chance they had to interact in-world with their classmates. It is worth mentioning that the students did not really opt for in-world communication with their classmates (see Section 3.3.2) - this is not surprising because they were located in the same classroom.

Statement 7 (...was interesting since I had the opportunity to see my creations "alive.") (see Table 10). Note that this statement has no corresponding statement in the "student-tostudent" category, as this is a feature that can exist within the virtual world exclusively. More than three out of four students gave a condescending response regarding the opportunity given to them to see their creations "alive." They agreed that seeing their code operating within the context of a virtual world was interesting for them. The mode of this statement falls on the "Agree" reply, with the negative responses being almost nonexistent. Indeed, it is worth mentioning that this statement, along with statement number twenty-nine, has the highest mean (3.98) among all statements of the survey, something which clearly demonstrates the strong trend of the sample to have a positive attitude towards that statement.

Students' opinion is in agreement with the observation findings (see Section 3.3). It indicates that students think of the opportunity they had to see their code operating in realtime-unlike other classic programming-teaching methods, for example, using a compiler-based user interface-as an interesting way of learning.

Statements 8 and 25 (...was fun.) (see Table 11). The majority of students enjoyed the use of the virtual world because of the student-to-world and the student-to-student interactions occurring in-world. Both statements had the same number of positive replies, but the statement regarding participants' enjoyment of the student-to-world interactions had a "Strongly Disagree" reply, whilst the statement regarding the student-to-student interactions had none.

The sample seems to agree with the statement that student-to-world interactions made them enjoy the practical session, and even though the standard deviation of the replies is quite high (0.97), the mean is not influenced and the sample tends to agree with the statement too. The same applies to the responses on the statement regarding student-to-student interactions, which has a lower standard deviation (0.87) and both mean and mode on "Agree."

Learning while having fun is the key of game-based learning [7, 26, 33] and, as the participants stated, they really enjoyed their time while working on their projects inworld. Interacting within the context of the virtual world both with its content and with their classmates made students enjoy their in-world experience and the practical sessions by extension.

Statements 9 and 26 (...made the practical session more attractive for me.) (see Table 12). The majority of the participants considered the use of the virtual world as an attractive alternative for their practical sessions. Both statements gathered mostly positive responses and very few negative. Nevertheless, it is worth mentioning that several participants had a neutral position.

In both cases, the mode and the mean are on the "Agree" response, but, overall, participants' responses regarding student-to-student interactions on this statement were slightly more positive (3.88) than those of the student-toworld interactions (3.8).

These findings clearly demonstrate a positive attitude regarding the way the learning material was delivered to students. Indeed, the whole process was fairly attractive for most of them, which is more obvious when looking at the findings regarding the student-to-student interactions. More specifically, it seems that the opportunity given to students to work in groups or interact with their fellow students simultaneously made the practical sessions more attractive for them.

Statements 10 and 27 (...made learning easier for me compared to just studying.) (see Table 13). In these statements, participants provided very positive feedback regarding the ease of learning within a virtual world. The neutral along with the negative replies consist of a very small portion of the sample compared to the replies with a positive stance.

The mode and the standard deviation (0.9/0.88) in both statements (i.e., interactions between the students and 
TABLE 10: Results of statement $7(n=50)$.

\begin{tabular}{lcccccc}
\hline $\begin{array}{l}\text {..was interesting since I had } \\
\text { the opportunity to see my } \\
\text { creations "alive." }\end{array}$ & $\begin{array}{c}\text { Strongly } \\
\text { Agree }\end{array}$ & Agree & $\begin{array}{c}\text { Neither } \\
\text { Agree nor } \\
\text { Disagree }\end{array}$ & Disagree & $\begin{array}{c}\text { Strongly } \\
\text { Disagree }\end{array}$ & $\begin{array}{c}\text { Mean } \\
\text { Standard } \\
\text { deviation }\end{array}$ \\
\hline 7 & 12 & 28 & 7 & 3 & 0 & 3.98 \\
\hline
\end{tabular}

TABLE 11: Results of statements 8 and 25 of the survey $(n=50)$.

\begin{tabular}{lcccccccc}
\hline ..was fun. & & $\begin{array}{c}\text { Strongly } \\
\text { Agree }\end{array}$ & Agree & $\begin{array}{c}\text { Neither } \\
\text { Agree nor } \\
\text { Disagree }\end{array}$ & Disagree & $\begin{array}{c}\text { Strongly } \\
\text { Disagree }\end{array}$ & $\begin{array}{c}\text { Mean } \\
\text { Standard } \\
\text { deviation }\end{array}$ \\
\hline 8 & Student-to-world & 13 & 23 & 9 & 4 & 1 & 3.86 & 0.97 \\
25 & Student-to-student & 12 & 24 & 10 & 4 & 0 & 3.88 & 0.87 \\
\hline
\end{tabular}

TABLE 12: Results of statements 9 and 26 of the survey $(n=50)$.

\begin{tabular}{|c|c|c|c|c|c|c|c|c|}
\hline \multicolumn{2}{|c|}{$\begin{array}{l}\text {...made the practical session } \\
\text { more attractive for me. }\end{array}$} & \multirow{2}{*}{$\begin{array}{c}\begin{array}{c}\text { Strongly } \\
\text { Agree }\end{array} \\
11\end{array}$} & \multirow{2}{*}{$\begin{array}{c}\text { Agree } \\
22\end{array}$} & \multirow{2}{*}{$\begin{array}{c}\text { Neither } \\
\text { Agree nor } \\
\text { Disagree }\end{array}$} & \multirow{2}{*}{$\begin{array}{c}\text { Disagree } \\
4\end{array}$} & \multirow{2}{*}{$\begin{array}{c}\text { Strongly } \\
\text { Disagree }\end{array}$} & \multirow{2}{*}{$\begin{array}{c}\text { Mean } \\
3.8\end{array}$} & \multirow{2}{*}{$\begin{array}{r}\begin{array}{r}\text { Standard } \\
\text { deviation }\end{array} \\
0.88\end{array}$} \\
\hline 9 & Student-to-world & & & & & & & \\
\hline 26 & Student-to-student & 9 & 28 & 11 & 2 & 0 & 3.88 & 0.75 \\
\hline
\end{tabular}

TABLE 13: Results of statements 10 and 27 of the survey $(n=50)$.

\begin{tabular}{lccccccc}
\hline $\begin{array}{l}\text {..made learning easier for me } \\
\text { compared to just studying. }\end{array}$ & $\begin{array}{c}\text { Strongly } \\
\text { Agree }\end{array}$ & Agree & $\begin{array}{c}\text { Neither } \\
\text { Agree nor } \\
\text { Disagree }\end{array}$ & Disagree & $\begin{array}{c}\text { Strongly } \\
\text { Disagree }\end{array}$ & $\begin{array}{c}\text { Mean } \\
\text { Standard } \\
\text { deviation }\end{array}$ \\
\hline 10 & Student-to-world & 9 & 28 & 8 & 4 & 1 & 3.8 \\
27 & Student-to-student & 10 & 28 & 8 & 3 & 1 & 3.86 \\
\hline
\end{tabular}

the world and the students with other students) are almost equal, with the trend of the sample being "Agree." Once again, the response to this statement regarding student-tostudent interactions had slightly higher mean (3.86) than the statement regarding the student-to-world interactions (3.8).

Learning is by default a tough process, and, so, ways to make it easier have always been of important concern. Participants' positive opinion regarding the advantages of using this learning method can be seen in their statements. However, almost one quarter of the participants had either neutral or even negative opinion.

Statement 11 (...pleased me a lot, especially when I was building and scripting.) (see Table 14). Participants expressed a positive opinion about the chance given to them in-world to build and script. The majority stated that this kind of interaction with the world pleased them a lot, a few had neutral feelings about these interactions, and only two pointed out that these interactions had not been pleasant for them. The mode of this statement was "Agree" and the standard deviation was not very high (0.75). Thereafter, the sample seems to tend to agree with the statement.

Building and scripting seem to have been a gratifying or satisfying activity for most of the students. While most of them enjoyed their assignments in the game-like environment, a considerable number of others seem to have thought of it as nothing more than a common assignment that they had to perform and, thus, had neutral feelings towards it.

Statement 12 (...pleased me a lot, especially when I was exploring and sightseeing.) (see Table 15). More than three out of five students responded positively on the statement regarding their enjoyment when exploring their classmates' workspaces and the content of the virtual world in general. However, some students stated that they had no particular feelings about exploring and sightseeing, whilst one out of ten participants did not enjoy these actions at all. The mode of this statement falls on the "Agree" reply and the standard deviation of the responses (0.75) does not influence the general tendency of the sample, which tends to agree with the statement.

Participants enjoyed exploring the content of the virtual world, seeing their classmates' and others' creations. Indeed, as observed (see Section 3.3.2) students were exploring the virtual world very often and that leads to the conclusion that this had been an action that they found enjoyable and rewarding. Moreover, when students were exploring others' workspaces they had the chance to use their objects and that was fulfilling for them, too, as shown by the responses on Statement 14 .

Statement 13 (...pleased me a lot, especially when I was using the virtual objects I created.) (see Table 16). Using their own 
TABLE 14: Results of statement 11 of the survey $(n=50)$.

\begin{tabular}{|c|c|c|c|c|c|c|c|}
\hline $\begin{array}{l}\text {..pleased me a lot, especially } \\
\text { when I was building and } \\
\text { scripting. }\end{array}$ & $\begin{array}{c}\text { Strongly } \\
\text { Agree }\end{array}$ & Agree & $\begin{array}{l}\text { Neither } \\
\text { Agree nor } \\
\text { Disagree }\end{array}$ & Disagree & $\begin{array}{l}\text { Strongly } \\
\text { Disagree }\end{array}$ & Mean & $\begin{array}{l}\text { Standard } \\
\text { deviation }\end{array}$ \\
\hline Student-to-world & 8 & 27 & 13 & 2 & 0 & 3.82 & 0.75 \\
\hline
\end{tabular}

TABLE 15: Results of statement 12 of the survey $(n=50)$.

\begin{tabular}{|c|c|c|c|c|c|c|c|}
\hline $\begin{array}{l}\text {...pleased me a lot, especially } \\
\text { when I was exploring and } \\
\text { sightseeing. }\end{array}$ & $\begin{array}{c}\text { Strongly } \\
\text { Agree }\end{array}$ & Agree & $\begin{array}{l}\text { Neither } \\
\text { Agree nor } \\
\text { Disagree }\end{array}$ & Disagree & $\begin{array}{l}\text { Strongly } \\
\text { Disagree }\end{array}$ & Mean & $\begin{array}{l}\text { Standard } \\
\text { deviation }\end{array}$ \\
\hline Student-to-world & 7 & 24 & 14 & 4 & 1 & 3.64 & 0.9 \\
\hline
\end{tabular}

TABLE 16: Results of statement 13 of the survey $(n=50)$.

\begin{tabular}{lcccccc}
\hline $\begin{array}{l}\text {..pleased me a lot, especially } \\
\text { when I was using the virtual } \\
\text { objects I created. }\end{array}$ & $\begin{array}{c}\text { Strongly } \\
\text { Agree }\end{array}$ & Agree & $\begin{array}{c}\text { Neither } \\
\text { Agree nor } \\
\text { Disagree }\end{array}$ & Disagree & $\begin{array}{c}\text { Strongly } \\
\text { Disagree }\end{array}$ & $\begin{array}{c}\text { Mean } \\
\text { Standard } \\
\text { deviation }\end{array}$ \\
\hline 13 & 4 & 34 & 10 & 0 & 2 & 3.76 \\
\hline
\end{tabular}

TABLE 17: Results of statement 14 of the survey $(n=50)$.

\begin{tabular}{lcccccc}
\hline $\begin{array}{l}\text {..pleased me a lot, especially } \\
\text { when I was using others } \\
\text { virtual objects }\end{array}$ & $\begin{array}{c}\text { Strongly } \\
\text { Agree }\end{array}$ & Agree & $\begin{array}{c}\text { Neither } \\
\text { Agree nor } \\
\text { Disagree }\end{array}$ & Disagree & $\begin{array}{c}\text { Strongly } \\
\text { Disagree }\end{array}$ & $\begin{array}{c}\text { Mean } \\
\text { Standard } \\
\text { deviation }\end{array}$ \\
\hline 14 & 8 & 24 & 17 & 0 & 1 & 3.76 \\
\hline
\end{tabular}

in-world artifacts was a very fascinating action for the vast majority of participants, as demonstrated in their responses. Almost four out of five students agreed with the statement that using their virtual objects was a pleasant part of their student-to-world interactions. Only one out of five students gave a neutral response and two out of the whole sample disagreed strongly. The mode of the replies falls on "Agree" and the general tendency of the sample is to agree that using their virtual creations was satisfactory for them. The relatively low standard deviation (0.77) shows that the replies were mostly gathered around the "Agree" response.

Students were inclined to use more of their own virtual creations. Using their own artifacts and seeing their performance had been a very pleasant and congenial action for them. Indeed, students were using very often their own virtual objects and really enjoyed demonstrating their performance to their classmates, as observed during their practical sessions (see Section 3.3.2).

Statement 14 (...pleased me a lot, especially when I was using others' virtual objects) (see Table 17). More than half of the participants stated that using their classmates' artifacts was a part of the student-to-world interactions that overjoyed them. A considerable number of participants stated that this kind of interactions had neither a rather negative nor a rather positive effect on them, and only one participant made very negative comments on them. "Agree" was the mode to these statements and standard deviation was up to 0.8 . The sample in general tends to have a positive stance towards it, agreeing that using others' virtual creations was of great interest and offered great satisfaction to them.

Students stated that they enjoyed the use of their classmates' artifacts and, as an observer, it was very often that they "visited" others' workspaces to have a look at the progress of their work and the performance of their scripts (see Section 3.3.2). However, the students' positive feelings and the fact that they were intrigued when they were using their classmates' artifacts accounts for the high rate on the neutral response.

Statement 21 (...made me more open and positive to collaborations.) (see Table 18). Even though the mode of the statement that student-to-student interactions made participants open and positive to collaboration was "Agree," as this was the answer with the highest count, an important conflict exists between the participants who chose this reply against those who were neutral. On the other hand, "Strongly Agree" and "Disagree" gathered fairly few replies, while "Strongly Disagree" got none. The trend of the sample is positive ("Agree") and standard deviation is quite low (0.78) with the replies being spread mostly between "Agree" and "Neither Agree nor Disagree."

Collaboration is something which most of the educators try to enhance, develop, and teach to their students [7, 33, 34]. However, several participants kept a neutral position towards this statement. This can be attributed to the freedom given to the students to decide whether they wish to work in groups or individually. This opinion is, however, in disagreement 
TABLE 18: Results of statement 21 of the survey $(n=50)$.

\begin{tabular}{lcccccc}
\hline $\begin{array}{l}\text {..made me more open and } \\
\text { positive to collaborations. }\end{array}$ & $\begin{array}{c}\text { Strongly } \\
\text { Agree }\end{array}$ & Agree & $\begin{array}{c}\text { Neither } \\
\text { Agree nor } \\
\text { Disagree }\end{array}$ & Disagree & $\begin{array}{c}\text { Strongly } \\
\text { Disagree }\end{array}$ & $\begin{array}{c}\text { Mean } \\
\text { Standard } \\
\text { deviation }\end{array}$ \\
\hline 21 & Student-to-student & 6 & 23 & 18 & 3 & 0 \\
\hline
\end{tabular}

TABLE 19: Results of statement 22 of the survey $(n=50)$.

\begin{tabular}{lcccccc}
\hline $\begin{array}{l}\text {...made me learn what other } \\
\text { users already knew. }\end{array}$ & $\begin{array}{c}\text { Strongly } \\
\text { Agree }\end{array}$ & Agree & $\begin{array}{c}\text { Neither } \\
\text { Agree nor } \\
\text { Disagree }\end{array}$ & Disagree & $\begin{array}{c}\text { Strongly } \\
\text { Disagree }\end{array}$ & $\begin{array}{c}\text { Mean } \\
\text { Standard } \\
\text { deviation }\end{array}$ \\
\hline 22 & 9 & 27 & 9 & 5 & 0 & 3.8 \\
\hline
\end{tabular}

TABLE 20: Results of statement 23 of the survey $(n=50)$.

\begin{tabular}{lcccccc}
\hline $\begin{array}{l}\text {..made me teach other users } \\
\text { things I knew. }\end{array}$ & $\begin{array}{c}\text { Strongly } \\
\text { Agree }\end{array}$ & Agree & $\begin{array}{c}\text { Neither } \\
\text { Agree nor } \\
\text { Disagree }\end{array}$ & Disagree & $\begin{array}{c}\text { Strongly } \\
\text { Disagree }\end{array}$ & $\begin{array}{c}\text { Mean } \\
\text { Standard } \\
\text { deviation }\end{array}$ \\
\hline 23 & 8 & 25 & 12 & 5 & 0 & 3.72 \\
\hline
\end{tabular}

with their replies on the two following statements and the observation findings that clearly demonstrate a strong collaborative trend (see Section 3.3.1).

Statement 22 (...made me learn what other users already knew.) (see Table 19). The majority of participants agreed with the statement that student-to-student interactions made participants learn what their fellow students knew. The same number of students (9) gave a very positive and neutral reply to this statement, whilst five answered negatively. Generally, the sample tends to agree with the statement, since the mean was up to 3.8, which indicates the "Agree" reply.

Based on participants' replies on this and the following statement, the fact that the virtual world offered great opportunities for peer-tutoring can be assumed. Interacting with each other within a virtual world in the context of practical sessions gave students the chance to be unofficially taught from their fellow students, share their experiences, and learn through them.

Statement 23 (...made me teach other users things I knew.) (see Table 20). The mode of the statement-which essentially consists of the opinion of half of the participants-regarding peer-tutoring as a teaching strategy performed in the virtual world is on "Agree" and the same applies to the trend (3.72) of the sample. In addition to this, eight participants stated that they helped to the maximum extent their fellow students to understand how the virtual world works ("Strongly Agree"). Less than one quarter of the sample provided support of minor importance to others ("Neither Agree nor Disagree") and finally five stated that they gave no support at all ("Disagree").

It seems that the use of such a virtual world encouraged a significant amount of students to help others-possibly more freely compared to other traditional teaching methods-to understand the operation of the virtual world, in general, and, later on, the functionality of the Linden Scripting Language
(LSL). This conclusion can be drawn from the observatory findings too, as most of the students used to assist each other during the whole process. Nevertheless, the use of a virtual world or any other pedagogical method would not cause any significant difference at all to students that were used to working in groups, helping each other to achieve their goals. That may justify the high frequency of neutral responses.

Statement 24 (...was interesting since I had the opportunity to chat with others about our projects.) (see Table 21). More than three out of five students agreed or strongly agreed that the discussion with their classmates about their projects had been an interesting part of their in-world interactions. Thirteen participants expressed a neutral opinion on this statement and four were opposed to it. The mean of the responses on this statement (3.78) shows that the sample tends to agree with it.

According to participants' replies, exchanging ideas about their projects had been an interesting part of students' inworld interactions for most of them. However, a considerable number of students did not consider this part of communication with their classmates as very interesting. Probably those students thought of these interactions only as part of their usual and necessary communication with their classmates in the context of a project and not as something special and more interesting beyond that.

Statement 28 (...pleased me a lot, especially when collaborating with others for a common goal.) (see Table 22). A major part of the sample gave positive feedback on the statement regarding the enjoyment of collaboration for the achievement of a common goal. Specifically, five participants agreed strongly with that statement and more than the half (twentyseven) agreed that working with others satisfied them a lot. However, like Statement 23, twelve students consider it as not something special ("Neither Agree nor Disagree") whilst six expressed their disagreement. Finally, both the mode and the trend (3.62) of the sample are on "Agree." 
TABLE 21: Results of statement 24 of the survey $(n=50)$.

\begin{tabular}{lccccccc}
\hline $\begin{array}{l}\text {..was interesting since I had } \\
\text { the opportunity to chat with } \\
\text { others about our projects. }\end{array}$ & $\begin{array}{c}\text { Strongly } \\
\text { Agree }\end{array}$ & Agree & $\begin{array}{c}\text { Neither } \\
\text { Agree nor } \\
\text { Disagree }\end{array}$ & Disagree & $\begin{array}{c}\text { Strongly } \\
\text { Disagree }\end{array}$ & $\begin{array}{c}\text { Mean } \\
\text { Standard } \\
\text { deviation }\end{array}$ \\
\hline Student-to-student & 10 & 23 & 13 & 4 & 0 & 3.78 & 0.86 \\
\hline
\end{tabular}

TABLE 22: Results of statement 28 of the survey $(n=50)$.

\begin{tabular}{|c|c|c|c|c|c|c|c|}
\hline $\begin{array}{l}\text {...pleased me a lot, especially } \\
\text { when collaborating with } \\
\text { others for a common goal. }\end{array}$ & $\begin{array}{c}\text { Strongly } \\
\text { Agree }\end{array}$ & Agree & $\begin{array}{c}\text { Neither } \\
\text { Agree nor } \\
\text { Disagree }\end{array}$ & Disagree & $\begin{array}{l}\text { Strongly } \\
\text { Disagree }\end{array}$ & Mean & $\begin{array}{l}\text { Standard } \\
\text { deviation }\end{array}$ \\
\hline Student-to-student & 5 & 27 & 12 & 6 & 0 & 3.62 & 0.83 \\
\hline
\end{tabular}

As previously noted, collaboration is not always a pleasant and enjoyable process to go through. It might or might not be a coincidence that the virtual world helped students collaborate in a more enjoyable way. Further research is necessary to confirm this finding. What is really worth keeping out of these findings is the nonexistent strong disagreement towards that statement and also the (probably unexpected) high number of positive replies.

Statement 29 (...pleased me a lot, especially when we were laughing with our mistakes.) (see Table 23). Participant's feedback on this statement was very positive. Almost $80 \%$ of the sample mentioned that laughing with their mistakes had been a very amusing and fun part of student-to-student interactions, few participants thought of them as neither pleasant nor unpleasant, whilst only one of them thought that this had been an unpleasant experience. The mean (3.98) of the replies corresponds with the mode ("Agree") and shows that the sample tends to agree with the statement. The replies on this statement along with those on Statement 7 had the highest means among all the statements of this survey. These two statements had the clearest possible "Agree" as the sample's tendency.

Students really enjoyed working within the virtual world, especially when seeing that their mistakes had unexpected results on their in-world creations. Referring back to Statement 7 and combining those findings with these of this statement, one can easily understand that the coding visualization-which the use of a virtual world enables, unlike many compilers - can be challenging and stimulating, even when the coding results are nor the expected neither the desired ones.

Statement 30 (...pleased me a lot, especially when we were having breaks from our work.) (see Table 24). Interacting with their fellow students in-world when they were having breaks from their work had been amusing for most of the participants. More than half of them gave a positive reply, several gave a neutral reply, and only a few answered negatively. The mean (3.52) shows that participants tend to agree, however slightly, to the statement. The high frequency of neutral replies affects the mean and thus the central tendency of the sample, which is very close to being "Neither Agree nor Disagree."
The opportunity given to students to explore the work and communicate with others as well as modify their avatars while taking breaks from their work seems to be an advantage for most of them. However, the main reason for using the virtual world was in the context of a university assignment, something which should not be disregarded. Finally, the fact that this statement got very few negative replies is very encouraging.

3.2. Reflection of the Survey Data. The findings derived from the questionnaires clarified, to a great extent, students' feelings and opinions towards the interactions occurring within a virtual world in the context of their academic practices. In general, student-to-world interactions had more positive impact on student engagement in the activities compared to in-world student-to-student interactions. Besides, the unique feature of student-to-world interactions that virtual worlds have is the primary reason for students to use them, since they are innovative enough for them to attract and maintain their interest [34].

3.2.1. In-World Interactions Both with the World and among Students. Indeed, it can be argued that the complex network of interactions occurring within a virtual world benefits the learning activities taking place within them in multiple ways. Participants responded that in-world interactions contributed positively on the appeal of both the learning material accessed in-world and the related practical sessions. Consequently, students' willingness to engage in the course material and, therefore, in the task of their assignment was significantly enhanced. This is also indicated by the fact that they enjoyed the sessions, as stated in the corresponding statements. Nevertheless, the learning process was facilitated too, since the use of the virtual world gave students the opportunity to have real-time awareness of the results of their work and immediate feedback from their copresent class mates on it.

3.2.2. In-World Interactions with the Content of the World. Student-to-world interactions seem to have substantially greater impact-compared to the in-world student-tostudent interactions-on four aspects: (1) students stated that interacting with the content of the virtual world helped 
TABLE 23: Results of statement 29 of the survey $(n=50)$.

\begin{tabular}{lccccccc}
\hline $\begin{array}{l}\text {..pleased me a lot, especially } \\
\text { when we were laughing with } \\
\text { our mistakes. }\end{array}$ & $\begin{array}{c}\text { Strongly } \\
\text { Agree }\end{array}$ & Agree & $\begin{array}{c}\text { Neither } \\
\text { Agree nor } \\
\text { Disagree }\end{array}$ & Disagree & $\begin{array}{c}\text { Strongly } \\
\text { Disagree }\end{array}$ & Mean & $\begin{array}{r}\text { Standard } \\
\text { deviation }\end{array}$ \\
\hline $29 \quad$ Student-to-student & 11 & 28 & 10 & 1 & 0 & 3.98 & 0.71 \\
\hline
\end{tabular}

TABLE 24: Results of statement 30 of the survey $(n=50)$.

\begin{tabular}{lcccccrr}
\hline $\begin{array}{l}\text { \#.pleased me a lot, especially } \\
\text { when we were having breaks } \\
\text { from our work. }\end{array}$ & $\begin{array}{c}\text { Strongly } \\
\text { Agree }\end{array}$ & Agree & $\begin{array}{c}\text { Neither } \\
\text { Agree nor } \\
\text { Disagree }\end{array}$ & Disagree & $\begin{array}{c}\text { Strongly } \\
\text { Disagree }\end{array}$ & Mean & $\begin{array}{r}\text { Standard } \\
\text { deviation }\end{array}$ \\
\hline $30 \quad$ Student-to-student & 2 & 27 & 18 & 1 & 2 & 3.52 & 0.79 \\
\hline
\end{tabular}

them experience the learning material and, on top of that, have real-time awareness of the results of their work, since these were visualised in 3D representations. (2) An increased level of willingness and enthusiasm to participate in practical sessions was mentioned. However, students noticed that similar-yet slightly more limited-impact on their perception about and attitude towards the virtual world had their interactions with their fellow students. (3) The interactions that students can have with the content of a virtual world can have some unique impacts that derive from unique features of virtual worlds and the benefits these can have on learning. More precisely, the 3D element turned coding into a stimulating activity, since students were enabled to observe $3 \mathrm{D}$ objects that they had created themselves perform actions. Not only the creation of virtual objects but also the use of them was interesting and pleasant habits for students. As they stated, they enjoyed both using their own virtual creations and also exploring the content of the world, that is, seeing and testing their classmates' artifacts. (4) For that particular cohort of students, building and scripting in a virtual world had been the core part of their assignment, and the reflection of their responses to this part of the questionnaire provides a clear indication that this kind of activities can significantly increase student engagement in the learning material.

3.2.3. In-World Interactions with Fellow Students. Even though student feelings about their interactions with the content of the virtual world were more positive compared to those about their in-world interactions with their fellow students, there was one point identified where student-tostudent interactions had more positive impact. Specifically, students responded that, despite the fact that all kinds of inworld interaction enhanced the appeal of the sessions, the interactions among them was the most fascinating part.

Student interactions with their classmates seemed to have some additional positive impacts on the learning process. Students became more open and positive-though slightlyto collaborations, since the use of this new medium encouraged them to cooperate in order to acquire the necessary for the completion of their assignment skills. Peer-tutoring was also encouraged and students seemed very willing to both assist their fellow students and learn from them. Finally, turning the practical session and the assignment into being more interesting for the students seems to be one more advantage derived from the in-world student-to-student interactions.

Student-to-student interactions did not seem to have influenced student engagement as extensively as student-toworld interactions. However, their potentials on engagement and learning truly exist and should not be disregarded.

The above findings are confirmed and enhanced to a great extent by the observatory findings that follow. However, there are some points where the findings from the survey and those from the observations did not totally coincide, and this fact raises some questioning that will be presented in the following sections.

3.3. Data Derived from the Observations. Participants' interactions and behaviors both in the physical classroom and in the virtual world were being observed for four weeks. In order to collect and analyse the observatory data using a systematic approach, we identified three different categories of data derived from the observations in the physical classroom and five different categories of data derived from the observations within the virtual world. Among the two types of observations, that is, in the physical classroom and within the virtual world, two categories were identified in common; these, namely, were (1) talking and commenting and (2) student identity and avatar identity. Student attitude was the third category we identified for the observations that took place in the physical classroom. On the other hand, (1) the inworld nonverbal communication, (2) students' willingness to remain in-world, and (3) the interactions students' had with the (virtual) world could only be examined as part of the in-world observations. Based on these categories we present, analyse, and compare the collected data in order to validate and enhance the findings derived from the surveys aiming to achieve clear and strong conclusions.

\subsubsection{In the Physical Classroom}

\section{(A) Talking and Commenting}

Observation 1 . Students were communicating verbally during the whole process. Their conversations were focused on the project and the use of the virtual world and never disoriented to irrelevant issues. They were commenting positively about 
the technology and their emotional experience, until approximately 50 minutes after the beginning of the session when the server crashed for five (5) minutes and all students made short negative comments about the technology of the virtual world. Despite that, they continued discussing enthusiastically about their in-world experience and making plans of what to create. They continued talking and commenting positively about the world and their projects until the end of the session. The most positive comments expressed in class by students were that coding in OpenSim is more preferred compared to other compilers where the user is unable to observe the functionality of the code unless active Graphical User Interface exists (such as in Eclipse), that the interaction of the world is rather alluring and appealing, and that the use of the virtual world in general is "fun," "interesting," and "enjoyable."

Observation 2. Students were collaborating and exchanging ideas about their projects, no matter if they were in the same group or not. They were also asking the demonstrator questions about building and scripting as well as about the world's functionalities in general. However, they were much less talkative than the previous session. Even when the server crashed for 5 minutes, students did not stop discussing about their projects and the way the in-world tools are used.

Students' positive comments about the technology of the virtual world and students' emotional experiences were expressed during the whole course of the session. Students were referring enthusiastically to the scripting and development opportunities given in-world and comments such as "I can create whatever I like here" were heard in-class. Some students even became emotionally attached to their creations. Nevertheless, all students made a negative comment about the technology of the world when the server crashed and the virtual world was no more accessible.

Observation 3. During the first 30 minutes, students were interacting verbally with their team members or fellow students very few times, commenting on each other's achievements, artifacts, and projects, and congratulating each other on the results of their work. When the server crashed for 5 minutes students kept talking to each other about their projects and exchanging ideas about further development. As soon as the server was restored, students continued to work without communicating extensively with each other. Approximately 1 hour after the beginning of the session, students were talking to each other more, helping their classmates to improve their artifacts, and asking for feedback regarding their work. All students were asking for the demonstrator's help on the development of complex scripts, whilst two students were asking for help struggling with the technology.

Students expressed themselves with quite positive remarks with regard to their pleasance. The opportunity given to students to combine the $3 \mathrm{D}$ content creation along with a scripting language was mentioned as an important advantage; they were surprised by the fact that they could create everything they might imagine. However, it is also worth mentioning that one of the students asked the demonstrator about the scope of the project they were involved in. That student seemed to be struggling with the technology of the world. This fact gave the indication that there might be some students who were not able to understand the value of the assignment due to lack of proper orientation.

Observation 4. Students' in-class communication was very limited at the beginning of the session. They were occasionally asking their partner and other classmates to provide them with feedback on their work. They were also asking the demonstrator to give them feedback on their work based on the requirements of their assignment and also some ideas on what else they could do to improve their work and, by extension, their grade. As time went by and students were facing several difficulties as far as the development was concerned, they started talking more and more to each other. They were proposing different plans to overcome their problems and arguing with their pairs about what the best solution could be.

In general, students were making positive comments about their in-world experience but two of them mentioned that they could not understand the reason of using this virtual world in the context of their practical session, its advantages, and potentials. Negative comments about the technology of the virtual world were made only when the server crashed, since that interrupted the students' experience in the virtual world.

\section{(B) Students' Attitude}

Observation 1. Students were very focused on their project during the whole session. They interrupted their work only in cases when they wanted to make comments about the virtual world or present their work to their classmates or ask the demonstrator questions regarding the technology of the world, building, and scripting. Only one student seemed to be absent-minded for a short period of time in a case when she seemed to be struggling and not knowing how to continue with her work.

In general the attraction of the world was deemed quite positive with a slight deviation among them. They seemed displeased only in the case when the server crashed and in cases when they experienced latencies or glitches of the world's technology.

Observation 2. Students were very focused on their projects during the whole session but still enjoying the use of the virtual world. One or two students seemed absent-minded for a couple of minutes once or twice when they did not know how to go on with their project. None of them was displeased while using the virtual world but all students were disappointed when the server crashed; they had no access to the world and they had to stop all their in-world actions and interactions.

Observation 3. Apart from one student, who was observed to be absent-minded for a couple of minutes, the rest were working focused on their projects, testing their work and 
the work of their group mates and enjoying their time in-world. However, after having checked the assignment's requirements, most of them seemed to be quite "stressed", as they were not sure whether their work would meet most of (if not all) the needs of the marking scheme.

Observation 4. All students seemed very focused on their work and were working hard, since that was the last session regarding the use of the virtual world and tried hard to complete their projects and meet the lecturer's expectations. However, they all seemed to enjoy the use of the virtual world and expressed their enthusiasm every time a complex part of their work was completed successfully.

\section{(C) Student Identity and Avatar Identity}

Observation 1. Students referred to their avatars as "I" several times (13) mainly during the editing of their appearance and during the whole session in general. Phrases like "Look at my feet" and "Do you see that object next to me?" were heard in-class. Even more often (20 times) students were referring to their avatars in the third person using phrases like: "Look what he is doing" or "She is ugly." However, they never referred to their avatars in the second person or as object.

Observation 2. As in the previous session, students often used their avatars to show things in-world to their classmates. Thus, phrases such as "Look at that. I am standing next to it" were expressed by students who were referring to their avatars as "I." Fewer times students referred to their avatars as "it" when they were talking about the avatar itself, its appearance, and its movements.

Observations 3 and 4. Students were not observed to refer to their avatars at all. They were very focused on building and scripting and they were ignoring their avatars.

\subsubsection{In the Virtual World}

\section{(A) Talking and Commenting}

Observation 1. Even though the lecturer encouraged students to use the chat tool, the students hardly ever used it. On top of that, almost all of them had the chat window closed most of the time. More precisely, the chat was used only twice for something relevant to the project or the virtual world and 21 times for random chatting while students were getting accustomed with that tool. None of the students used the chat to express any feelings about the use of the virtual world, but phrases often used in social networks were used in chat twice ("LOL" and "O.M.G").

Observation 2. Students hardly ever used chat to communicate with each other. More often they used it to "call" their scripts, and even more often the chat was used by the scripts that display text on the chat. A few times chat was also used when students wanted to make comments about their classmates' artifacts such as "wow", "cool" and "lol". We observed only one case were two students used chat to exchange information about their projects. These students were located in different classrooms and one asked the other to give him some information about one of the scripts he had developed.

Observation 3. Students used the chat tool only to call the functions of their scripts. Also, the chat box was used for displaying scripted messages.

Observation 4. Students still did not seem interested in using the in-world chat. Since they were communicating verbally in class, the chat was mainly used for "calling" scripts and displaying scripted messages.

\section{(B) Student Identity and Avatar Identity}

Observation 1. All students spent 10-15 minutes to edit the appearance of their avatars. Most of the modifications they made were minor, changing only the basic features of their avatars, such as hair colour and length, skin and eyes colour, height and weight, clothing colour and type. During that time students referred to their avatars three times in chat using first person. The most characteristic example was when a student said "O.M.G. I am naked" when by mistake had removed all the clothes from the avatar.

Observation 2. All students had made further modifications on their avatars' appearance during the previous days. Some of them were still minor and basic and others were major and detailed. It seemed that some students spent considerable time between the sessions to make their avatar look according to their taste.

Observation 3. Only two students modified further their avatars during the practical session. However, none of the students called his/her avatar in the first person, neither in the second nor in the third one while chatting in-world.

Observation 4. One student was observed making further modification on avatar appearance. However, none referred to their avatars on chat, for as long as the observation lasted.

\section{(C) In-World Nonverbal Communication}

Observation 1. Students never used emoticons during that session but one used gestures twice while exploring the world's functions.

Observation 2. Students used gestures very rarely. Only one student was observed using gestures twice, while none used any emoticons.

Observation 3. Only one student used random gestures for about 10 times (in a row) without any specific reason. No use of emoticons was made at all by any of the students.

Observation 4. No student was observed using any gestures or emoticons.

\section{(D) Interactions with the World}

Observation 1. Students spent approximately 20 minutes exploring the virtual world walking and flying around. They chose their workspace and investigated the artifacts already existing on the island. Once they had seen most of the 
content of the world, students started performing actions to familiarise themselves with the navigation tools of the world. Most of them learned quickly to navigate themselves, but some others were struggling and made progress on a more moderate pace.

Approximately 40 minutes after their first login, students started making their first attempts to build and script. They created, deleted and even lost some basic objects; they tried to modify them slightly, write their first scripts and even searched the web for information about scripting. Students that had created scripted objects were using their own objects to test the operation of their scripts, modify them and even show them to others. Moreover, they created their first notecards.

Many students "visited" their classmates' workspaces to observe and use others' first objects.

Observation 2. Some students spent considerable time between this and the previous session to build and script in-world. When the previous session ended, students had created only some very basic objects and scripts (ranging from two to more than ten depending on student ability). Nevertheless, though, when this session began, the virtual world was full of new artifacts, some of which were very impressive, interesting, imaginative and creative.

Students were trying to copy and remake what the lecturer had demonstrated earlier. They were building, scripting, checking the functionality of their scripts, and several times they visited websites to look for information about scripting. They also used notecards.

Very often students were taking breaks from their work to see what others had created. They checked the functionality of others' scripts and tried to remake some of them.

Observation 3. Most of the students had worked on their projects quite a lot in the previous days, enhancing their artifacts and also further developing them when necessary. During the practical sessions, they were doing further scripting and testing of their own scripts, most of the times making fun of them while testing their functionality, as well as searching the web and books for Object Oriented Driven Programming paradigms in order to get more ideas to further improve their work. In addition to this, they were wandering (flying) around in order to visit and use their fellow students' scripts. The only in-world tool that they did make use of was the note-cards, which they used as part of their scripting agenda.

The students who were left behind managed to slightly improve their work during the second hour of this session.

Observation 4. Significant content and programming development was made since the last session. Most of the students developed considerably meaningful pieces of code whilst their artifacts had been fully shaped. Almost all of them were now fully familiar with the tools of the OpenSim technology (regarding the possibilities and limitations) whilst they were still researching complex scripting structures. They were building and scripting almost without disruption. They were taking breaks from their work only to see and use what their classmates had created often seeking inspiration about further modifications on their own artifacts.

It is worth mentioning that one of the students was observed building and scripting totally isolated from the rest of his classmates, under the sea surface. Another student preferred to build his "castle" up high in the air but still his artifacts could be easily visible by everyone in-world, since all students were flying around.

\section{(E) Willingness to Remain In-World}

Observation 1. Students were willing to stay in-world more than they were expected to. All of them stayed in-world for 30 more minutes after the lecturer announced the completion of the session.

Observation 2. Several students had logged-in 30 minutes prior to the session. Eight students logged out once they had finished their work and the lecturer announced the end of the session. Seven stayed in-world for 30 more minutes in order to make further modifications on their artifacts.

Observation 3. Two students stayed in-world for approximately 20 more minutes after the end of the session in order to complete their job. The rest of the students logged out from the virtual world as soon as their work was completed.

Observation 4. Five students were present in the virtual world and in-class 30 minutes before the beginning of the session. As soon as the session was completed, two (2) students were willing to stay in-world longer in order to complete their work.

\subsection{Reflection of the Observation Data}

3.4.1. In the Physical Classroom. At this point, the synopsis of the observed behaviors deemed to be purposeful. Some student behaviors and actions were observed much more frequently than others that were rarely or never observed. These students' choices to act in certain ways in conjunction with their statements on the survey can draw a clear and consistent picture about their attitude towards the use of a virtual world in the context of their academic studies.

(A) In-Class Talking and Commenting. Students were talking to each other, or the lecturer, or the demonstrator about their in-world projects, the virtual world and its potentials during the whole time of the practical sessions. Hardly ever was there anything irrelevant to the project or the virtual world heard in-class during the observed practical sessions. Students were very often making positive comments about the technology of the virtual world, its potential and their respective emotional experience.

Negative comments about the technology of the virtual world were only heard when students were facing latency or malfunction issues such as sever crashes. None of the students made a negative comment about the emotional experience of the virtual world. However, two or three of the students made some rather neutral comments, since they could not see 
anything special about the use of a virtual world as a learning tool.

(B) Student Attitude. With very few exceptions-for example, in cases where the server crashed or students were struggling with the world's technology,- -students seemed very focused on their projects enjoying the use of the virtual world during the whole course of the sessions. In overall, no student was observed to clearly dislike the use of the virtual world, but for some of them, who were struggling with its technology, the use of the virtual world was rather unpleasant occasionally.

It is worth mentioning that students' enthusiasm and excitement about the use of the virtual world was more intense on the first two sessions, whilst they were much more focused on the fulfillment of the tasks of their assignments on the last two sessions.

(C) Student Identity and Avatar Identity. Students referred to their avatars in the first person several times during the first and second practical sessions, but they referred to them in the third person, calling them he or she, more often than in the first person. They were not observed referring to their avatars at all during the third and fourth session. However, it should be mentioned that all students were possessive over their inword creations and were referring to them as "my [...]". This can give an indication that they were considering their avatars as an extension of themselves, or a very different view could be that they were considering them as tool or medium to interact in-world, but this needs to be further investigated.

No student was observed referring to their avatars in the second person or as object as long as the practical sessions lasted.

\subsubsection{In the Virtual World}

(A) In-World Talking and Commenting. Students were making very limited use of the chat tool to communicate with each other about their projects or the virtual world. In fact, the chat tool was minimized, most of the time mainly used to trigger scripts or to display scripted messages. Several times students expressed their enjoyment about using the virtual world and exhilaration about their classmates' activities through the chat tool. Only very few times did the students use in the chat words or phrases often used in social networks, and this indicates that they did have previous experience with similar online chatting tools. Thus, their reluctance to use chat cannot be attributed to unfamiliarity with such tools, but rather to their preference for in-class talking. However, none of them was observed chatting in-world about something irrelevant to the project or the virtual world, and also no negative comment about the technology or the emotional experience of the virtual world came to the observer's attention.

(B) Student Identity and Avatar Identity. Most of the students seemed to be very interested in changing their avatar appearance when they had their first contact with the virtual world. Some of them spent considerable time between sessions to modify their avatars according to their preferences. Fewer students were observed modifying their avatars' appearance during the next sessions. Thus, almost all students seemed to consider avatar appearance as part of their virtual identity. The development of a virtual body and a virtual identity is highlighted in [24] as part of the process of student engagement for effective learning in virtual worlds. However, there were very few students who did not modify their avatar appearance at all and preferred using the default avatar.

Generally, students were rarely observed referring to their avatars was quite limited when using the chat tool. During the first practical session few of them referred to their avatars in the first person, whilst no student was ever observed referring to their avatars in the second or third person or as an object.

(C) In-World Nonverbal Communication. A small range of students was rarely observed during the sessions using random gestures without obvious reason, probably throughout the process of exploring the world's functionalities, but emoticons were never observed being used.

(D) Interactions with the World. Students' time in-world was mainly spent on building and scripting, as they were working focused on their projects. Very often they were using their own scripted objects, either to test their functionality or to show their progress to their classmates. Moreover, throughout the course of the study all students were taking breaks from their own work to visit their classmates' workspaces, observe their progress on their projects, and test the functionality of their scripted objects. Unsurprisingly, the only in-world tool observed being used was the notecards, which were one of the assignment's requirements.

(E) Students' Willingness to Remain in-World Longer Than the Expected. From the very first week a significant number of students showed their interest in this new educational approach and opted to stay in-world longer than they were expected to. With the only exception of the first practical session, several students used to come online earlier than the starting time. Some students also opted not to logout after the completion of the session, but, instead, stayed online further so as to work on their projects or spend some of their spare time to interact with their fellow-students and explore the features of the virtual world

The majority of students were visiting the virtual world out of the mandatory practical session hours. Even though they were not observed during these hours, the results of their work could be clearly seen at the beginning of the next session. Besides, the data logs reveal that most of the students spent significant time in-world.

3.5. Triangulation of the Collected Data and Presentation of Taxonomy. Overall, the data collected from the surveys and observations seem to be grouped according to a number of points. Aiming to map and categorise all the interactions related to the use of a virtual world, Table 25 presents a taxonomy of them. This taxonomy includes all kinds of interactions observed during the experiment categorised according to two parameters: the context in which the interactions take place, that is, in-world or in-class, and the involved parts, 
TABLE 25: Taxonomy of the interactions related to the use of virtual worlds.

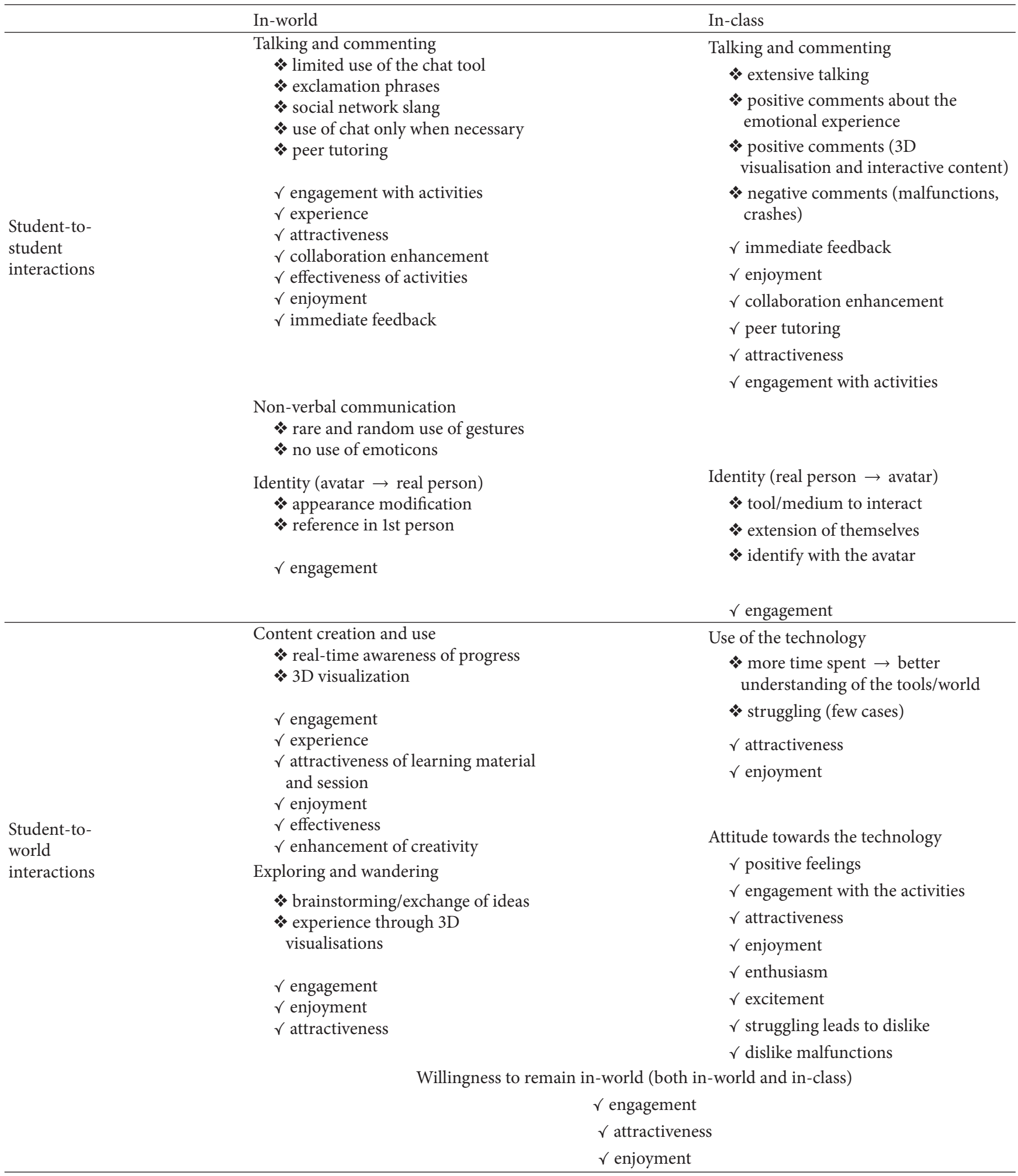

that is, students interacting with other students or students interacting with the virtual world.

Four categories of interactions derive from the combination of the context and the evolved in the interactions parts: (a) in-world student-to-student interactions, (b) inworld student-to-world interactions, (c) in-class student-tostudent interactions, and finally (d) in-class student-to-world interactions. Each one of the main cells of Table 4 illustrates 
a sub-category of these interactions. The various types of interactions related to that subcategory, as observed in-class and in-world during the practical sessions, are indicated with the symbol [ ], whilst the results of these interactions are indicated in the same cell with the symbol $[\checkmark]$.

The presentation of the interactions along with their corresponding results was considered to be truly helpful for educators who are planning to use a hybrid model of education with and within a virtual world where student can be co-present both in-class and in-world. It is important for them to be fully aware of the affordances of the world, and also of the interactions their students are expected to perform, in order to plan the in-world and in-class activities in ways that suit their needs and enhance the fulfillment of their educational goals.

Even though the following can be used as a map of complex network of student interactions, it enables educators and researchers to have a clear and holistic view of actions, interactions and results related to the use of such a tool. As the literature review in this paper has already shown, several researches focusing on and analysing in depth some of the aspects this paper has barely touched upon, and thus it is suggested the reader refer to those for in-depth analysis. However, a taxonomy that would present a complete view of the phenomena that relate to the use of virtual worlds was missing. This gap is now filled by this research.

Nevertheless, this study has brought to light several topics that require further investigation. Among them one can identify the topic of engagement in learning activities, and how that is enhanced through certain design and instructions of the learning activities. Clear indications of the fact that student interactions with the world and with each other can enhance student engagement were given during our experiment, but further research is needed for the drawing of substantial conclusions. Furthermore, clear guidance should be given to educators and instructors on how to create engaging educational activities for their students using virtual world and what interactions they should focus on in order to achieve that goal. These gaps will be filled from our ongoing research.

3.6. Limitations of the Study. The duration of this assignment was scheduled to be one (1) month and this turned to be the main limitation in our study. During this month our students had to explore the virtual world and learn its features but also work on their assignment and write their report. In addition, most of them had no previous experience with the use of such virtual world. Therefore, they did not have the chance to use all the features that the virtual world offers. Even though most of the students seemed to enjoy their time within the virtual world, it is hard to conclude whether they felt part of it or simply used it because of their duty to complete their assignment. It is also hard to generalise to different assignment types due to the very specific nature of this assignment. The focus of this study was on interactions and how they can affect student engagement in a strict timeframe and with a very specific scope. In other educational fields different conclusions can be drawn. Therefore, it is suggested that similar studies are conducted in order to cover different educational.

\section{Conclusions}

What needs to be pointed out through this study is that not only the interactions into a virtual world, which have been extensively investigated, but also the in-class interactions related to the use of a virtual world can maximise the benefits that are derived from the use of the virtual world per se. Surprisingly, during our experiment students spontaneously opted to use the interaction channels that were more suitable for their needs and adjusted to their habits or preferences. Consequently, they were using extensively the in-class communication channels (such as talking out loud), and at the same time exploited to a great extent the capabilities of the virtual world. Besides, this is the true meaning of hybrid models of using virtual worlds: exploiting to the maximum the affordances of the world, yet covering its drawbacks with the capabilities offered in the physical settings.

\section{Conflict of Interests}

The authors declare that there is no conflict of interests regarding the publication of this paper.

\section{References}

[1] P. G. Schrader, "Learning in technology: reconceptualizing immersive environments," Association for the Advancement of Computing In Education Journal, vol. 16, no. 4, pp. 457-475, 2008.

[2] A. Herbert, F. Thompson, and F. Garnier, "Immaterial art stock: preserve, document and disseminate the pioneering works of art created inside online immersive platforms," in Proceedings of the 2nd European Immersive Education Summit (EiED '12), M. Gardner, F. Garnier, and C. D. Kloos, Eds., pp. 101-113, Departamento de Ingeniería Telemática, Universidad Carlos III de Madrid, Paris, France, 2012.

[3] M. Frutos-Perez, "Practice, context, dialogue: using automated conversational agents to extend the reach and depth of learning activities in immersive worlds," in Proceedings of the World Conference on Educational Multimedia, Hypermedia and Telecommunications, pp. 70-77, Open University Press, Milton Keynes, UK, 2011.

[4] M. D. Dickey, "Brave new (interactive) worlds: a review of the design affordances and constraints of two 3D virtual worlds as interactive learning environments," Interactive Learning Environments, vol. 13, no. 1-2, pp. 121-137, 2005.

[5] C. Allison, A. Campbell, C. J. Davies et al., "Growing the use of Virtual Worlds in education: an OpenSim perspective," in Proceedings of the 2nd European Immersive Education Summit (EiED '12), M. Gardner, F. Garnier, and C. D. Kloos, Eds., pp. 113, Departamento de Ingeniería Telemática, Universidad Carlos III de Madrid, Paris, France.

[6] B. Dalgarno and M. J. W. Lee, "What are the learning affordances of 3-D virtual environments?" The British Journal of Educational Technology, vol. 41, no. 1, pp. 10-32, 2010.

[7] K. Bredl, A. Groß, J. Hünniger, and J. Fleischer, "The avatar as a knowledge worker? how immersive $3 \mathrm{~d}$ virtual environments 
may foster knowledge acquisition," The Electronic Journal of Knowledge Management, vol. 10, no. 1, pp. 15-25, 2012.

[8] C. M. Johnson, A. A. Vorderstrasse, and R. Shaw, "Virtual worlds in health care higher education," Journal of Virtual Worlds Research, vol. 2, no. 2, 2009.

[9] A. Hockey, F. Esmail, C. Jimenez-Bescos, and P. Freer, "Built environment education in the Era of virtual learning," in Proceedings of the W089-Special Track 18th CIB World Building Congress, pp. 200-217, Salford, UK, 2010.

[10] B. Carter, "Virtual harlem: an innovative past, an evolving present and an exciting future," in Proceedings of the 2nd European Immersive Education Summit (EiED '12), M. Gardner, F. Garnier, and C. D. Kloos, Eds., pp. 1-13, Universidad Carlos III de Madrid, Departamento de Ingeniería Telemática, Paris, France, 2012.

[11] M. Conrad, J. Neale, and A. Charles, "Of mice or men? The avatar in the virtualscape," in Proceedings of the International Conference on Information Society (i-society '10), London, UK, 2010.

[12] A. Christopoulos and M. Conrad, "Maintaining context in a changing (virtual) world: educators' perspectives for OpenSim and second life," in Proceedings of the 5th International Conference on Computer Supported Education (CSEDU '13), Aachen, Germany, 2013.

[13] S. Minocha and R. Tingle, "Socialisation and collaborative learning of distance learners in 3D virtual worlds," in Proceedings of the Researching Learning in Virtual Environments International Conference (RELIVE '08), Milton Keynes, UK, 2008.

[14] G. Veletsianos, "The impact and implications of virtual character expressiveness on learning and agent-learner interactions," Journal of Computer Assisted Learning, vol. 25, no. 4, pp. 345$357,2009$.

[15] C. Dede, "The evolution of constructivist learning environments: immersion in distributed virtual worlds," Educational Technology, vol. 35, no. 5, pp. 46-52, 1995.

[16] A. Padrós, M. Romero, and M. Usart, "Measuring the knowledge convergence process in the collaborative Game MetaVals," Procedia Computer Science, vol. 15, pp. 193-202, 2012.

[17] L. S. Vygotsky, Mind Society: The Development of Higher Mental Processes, Harvard University Press, Cambridge, Mass, USA, 1978.

[18] D. Jones, "An alternative (to) reality," in Understanding Learning in Virtual Worlds, M. Childs and A. Peachey, Eds., HumanComputer Interaction Series, pp. 1-20, Springer, London, UK, 2013.

[19] H. Zhao, B. Sun, H. Wu, and X. Hu, "Study on building a 3D interactive virtual learning environment based on OpenSim platform," in Proceedings of the International Conference on Audio, Language and Image Processing (ICALIP '10), pp. 14071411, Shanghai, China, November 2010.

[20] P. R. Anasol, V. Callaghan, M. Gardner, and M. J. Alhaddad, "End-user programming and deconstrutionalism for cocreative laboratory activities in a collaborative mixed-reality environment," in Proceedings of the 2nd European Immersive Education Summit (EiED '12), M. Gardner, F. Garnier, and C. D. Kloos, Eds., pp. 171-182, Departamento de Ingeniería Telemática, Universidad Carlos III de Madrid, Madrid, Spain, 2012.

[21] J. B. Elliott, M. Gardner, and M. Alrashidi, "Towards a framework for the design of mixed reality immersive education spaces," in Proceedings of the 2nd European Immersive Education Summit (EiED '12), M. Gardner, F. Garnier, and C. D. Kloos, Eds., pp. 63-76, Universidad Carlos III de Madrid, Departamento de Ingeniería Telemática, Paris, France, 2012.

[22] V. Camilleri, S. de Freitas, M. Montebello, and P. McDonaghSmith, "A case study inside virtual worlds: use of analytics for immersive spaces," in Proceedings of the 3rd International Conference on Learning Analytics and Knowledge (LAK '13), pp. 230-234, Leuven, Belgium, April 2013.

[23] S. de Freitas, G. Rebolledo-Mendez, F. Liarokapis, G. Magoulas, and A. Poulovassilis, "Developing an evaluation methodology for immersive learning experiences in a virtual world," in Proceedings of the Conference in Games and Virtual Worlds for Serious Applications (VS-GAMES '09), pp. 43-50, Coventry, UK, March 2009.

[24] M. Childs, Learners' experience of presence in virtual worlds [Ph.D. thesis], University of Warwick, Coventry, UK, 2010.

[25] J. Chafer and M. Childs, "The impact of the characteristics of a virtual environment on performance: concepts, constraints and complications," in Proceedings of the Researching Learning in Virtual Environments (ReLIVE '08), pp. 94-105, Open University, Milton Keynes, UK, 2008.

[26] J. Steuer, "Defining virtual reality: dimensions determining telepresence," Journal of Communication, vol. 42, no. 2, pp. 7393, 1992.

[27] J. Levesque and E. Lelievre, "Creation and communication in virtual worlds: experimentations with OpenSim," in Proceedings of the Virtual Reality International Conference (VRIC '11), S. Richir and A. Shirai, Eds., pp. 22-24, Laval, France, 2011.

[28] S. de Freitas, G. Rebolledo-Mendez, F. Liarokapis, G. Magoulas, and A. Poulovassilis, "Learning as immersive experiences: Using the four-dimensional framework for designing and evaluating immersive learning experiences in a virtual world," The British Journal of Educational Technology, vol. 41, no. 1, pp. 69$85,2010$.

[29] L. Cohen, L. Manion, and K. Morrison, Research Methods in Education, Routledge Taylor \& Francis, London, UK, 7th edition, 2011.

[30] N. J. Mount, C. Chambers, D. Weaver, and G. Priestnall, "Learner immersion engagement in the $3 \mathrm{D}$ virtual world: principles emerging from the DELVE project," Innovation in Teaching and Learning in Information and Computer Sciences, vol. 8, no. 3, pp. 40-56, 2009.

[31] I. Kostarikas, I. Varlamis, and A. Giannakoulopoulos, "Blending distance learning platforms and 3D virtual learning environments," in Proceedings of the 6th International Conference in Open Distance Learning, vol. 40, pp. 27-40, Loutraki, Greece, November 2011.

[32] B. G. Witmer and M. J. Singer, "Measuring presence in virtual environments: a presence questionnaire," Presence, vol. 7, no. 3, pp. 225-240, 1998.

[33] A. Christopoulos and M. Conrad, "Views of educators on immersion in virtual worlds from second life to OpenSim," in Proceedings of the 2nd European Immersive Education Summit (EiED '12), M. Gardner, F. Garnier, and C. D. Kloos, Eds., pp. 48-59, Universidad Carlos III de Madrid, Departamento de Ingeniería Telemática, Paris, France, 2012.

[34] E. Prasolova-Førland, "Analyzing place metaphors in 3D educational collaborative virtual environments," Computers in Human Behavior, vol. 24, no. 2, pp. 185-204, 2008. 

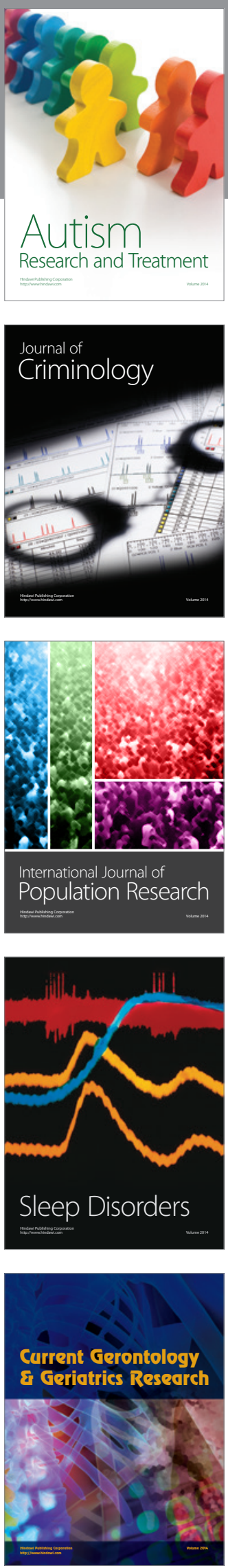
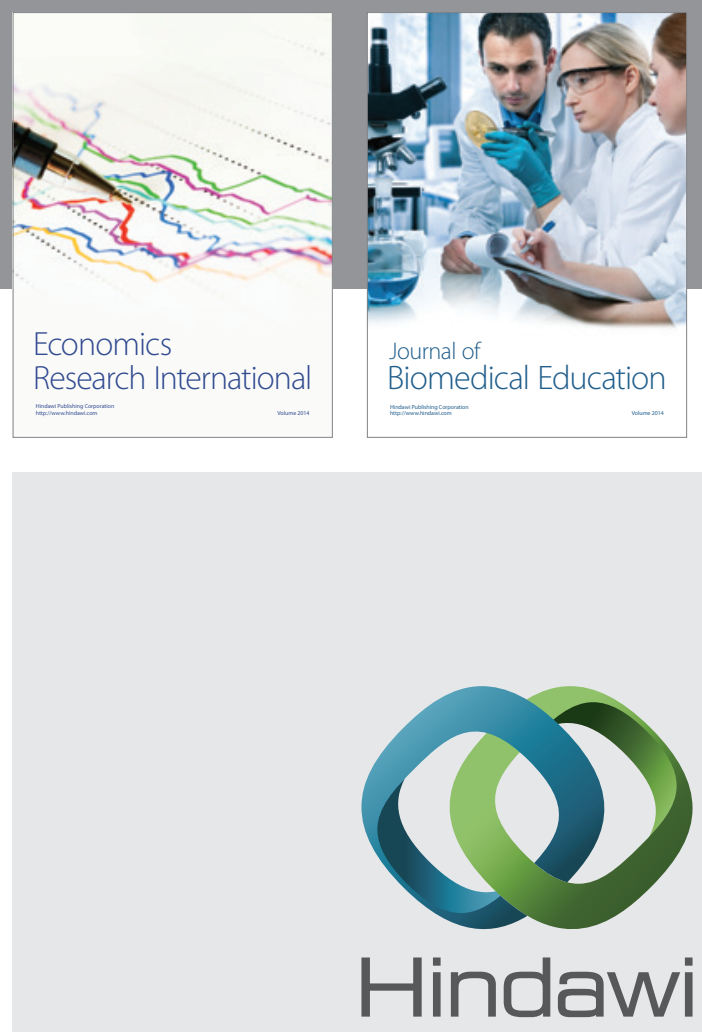

Submit your manuscripts at

http://www.hindawi.com
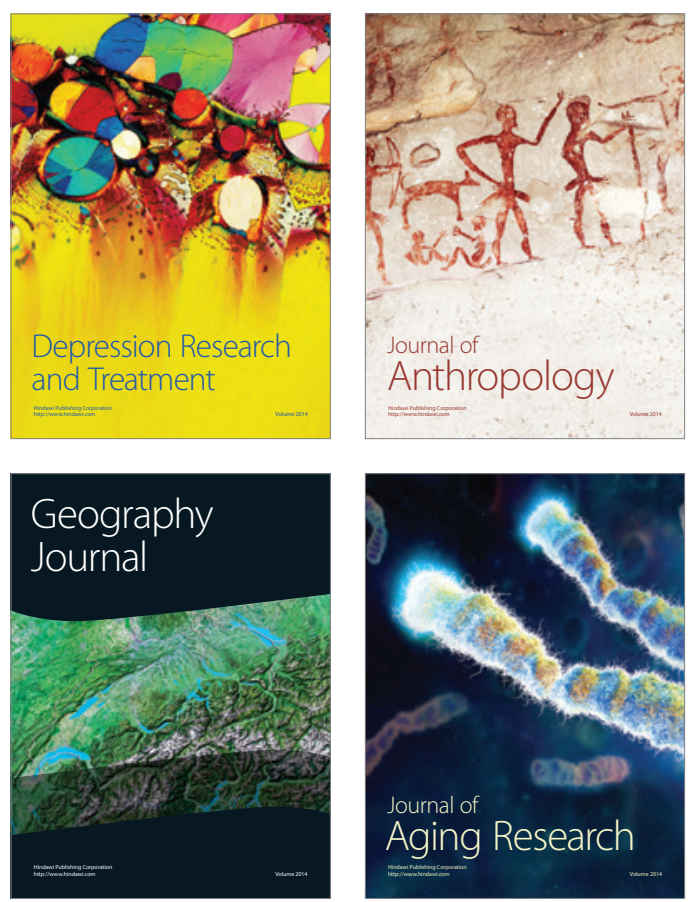
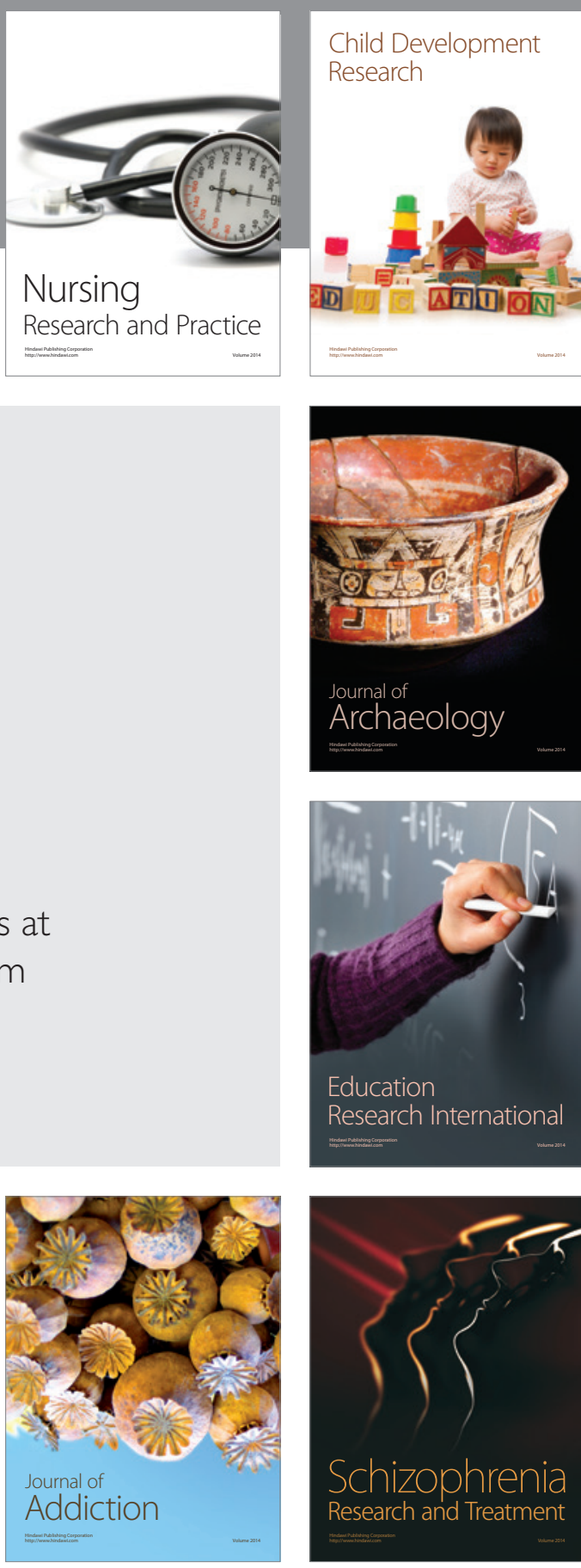

(D)
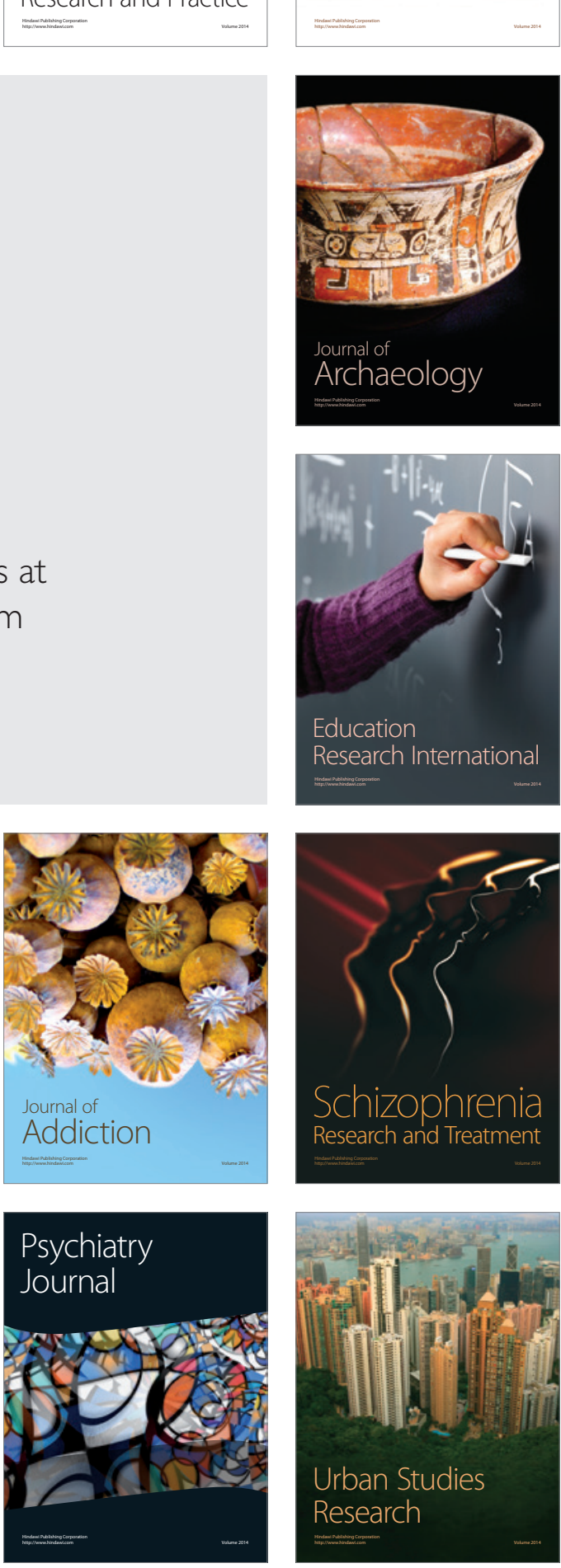